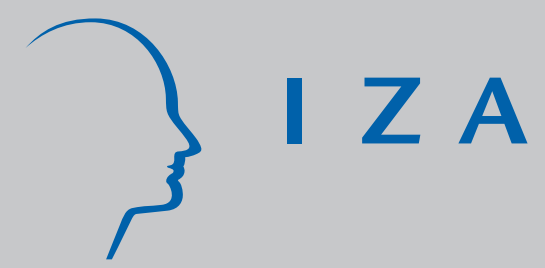

IZA DP No. 7412

Are Worker-Managed Firms Really More Likely to Fail?

Gabriel Burdín

May 2013

Forschungsinstitut zur Zukunft der Arbeit Institute for the Study of Labor 


\title{
Are Worker-Managed Firms Really More Likely to Fail?
}

\author{
Gabriel Burdín \\ IECON, Universidad de la República \\ and IZA
}

Discussion Paper No. 7412

May 2013

IZA
P.O. Box 7240
53072 Bonn
Germany

Phone: +49-228-3894-0

Fax: +49-228-3894-180

E-mail: iza@iza.org

Any opinions expressed here are those of the author(s) and not those of IZA. Research published in this series may include views on policy, but the institute itself takes no institutional policy positions. The IZA research network is committed to the IZA Guiding Principles of Research Integrity.

The Institute for the Study of Labor (IZA) in Bonn is a local and virtual international research center and a place of communication between science, politics and business. IZA is an independent nonprofit organization supported by Deutsche Post Foundation. The center is associated with the University of Bonn and offers a stimulating research environment through its international network, workshops and conferences, data service, project support, research visits and doctoral program. IZA engages in (i) original and internationally competitive research in all fields of labor economics, (ii) development of policy concepts, and (iii) dissemination of research results and concepts to the interested public.

IZA Discussion Papers often represent preliminary work and are circulated to encourage discussion. Citation of such a paper should account for its provisional character. A revised version may be available directly from the author. 


\section{ABSTRACT}

\section{Are Worker-Managed Firms Really More Likely to Fail?*}

Different theoretical explanations suggest that worker-managed firms (WMFs) are prone to failure in competitive environments. Using a long panel of Uruguayan firms, the author presents new evidence on firm survival comparing WMFs and conventional firms. Excluding microenterprises and controlling for differences in the effective tax burden faced by the two types of firms, the hazard of dissolution is $29 \%$ lower for WMFs than for conventional firms. This result is robust to alternative estimation strategies based on semi-parametric and parametric frailty duration models that impose different distributional assumptions about the shape of the baseline hazard and allow to consider firm-level unobserved heterogeneity. The greater survivability of WMFs seems to associated with the greater employment stability achieved in this type of firms. The evidence suggests that the marginal presence of WMFs in actual market economies can hardly be explained by the fact that these organizations exhibit lower survival chances than conventional firms.

JEL Classification: P13, P51, C41

Keywords: labor-managed firms, capitalist firms, survival analysis

Corresponding author:

Gabriel Burdin

Instituto de Economia, Universidad de la República

Joaquín Requena 1375

11200, Montevideo

Uruguay

E-mail: gburdin@iecon.ccee.edu.uy

\footnotetext{
* I am especially grateful to Sam Bowles, John Pencavel and Tiziano Razzolini, as well as to two anonymous referees and the editor of this journal for helpful comments. I would also like to thank to Andrés Dean, Giulio Ecchia, Catherine Guirkinger, Stephen Jenkins, Jean-Philippe Platteau, Andrés Rius and to seminar and workshop participants at IAFEP Conference, ERMES Paris II; EURICSE Summer School "New approaches to the study of enterprises: the role of motivation"; CRED, University of Namur; 2010 Ph.D Annual Meeting, University of Siena; University of Bologna; Facultad de Ciencias Económicas y de Administración, Universidad de la República for their useful comments. A previous version of this paper was awarded with the Horvat-Vanek Prize at the 2010 IAFEP Conference, Paris-II University and circulated as a working paper at the University of Siena and IECON, Universidad de la República.
} 


\section{Introduction}

Samuelson (1957) claims that in a perfectly competitive market it does not really matter who hires whom. In other words, it is irrelevant whether entrepreneurial functions are carried out either by capital or labor. This famous statement seems to be at odds with the fact that most firms in actual market economies are ultimately controlled by capital suppliers and not by their workforce.

Recent developments in economic theory have provided several competing explanations to account for these facts. One important concern in this debate is to determine whether the low proportion of worker-managed firms (WMFs) is explained by structural obstacles impeding their formation or by internal inefficiencies leading this type of firms to a higher rate of failure compared with conventional enterprises.

I provide an empirical assessment of the comparative survivability of WMFs and conventional firms (CFs) based on a long panel of Uruguayan firms. The study exploits social security administrative records containing monthly information on the total population of WMFs and CFs in 112 3-digit sectors over the period January 1997-July 2009. The empirical strategy is based on semi-parametric and parametric frailty survival models that impose different distributional assumptions about the shape of the baseline hazard and allow to consider firm-level unobserved heterogeneity.

This paper adds to the literature on labor-managed firms and its main contribution relies on the fact that empirical work on the effect of workers' control on firm survival is not frequent. Previous studies comparing worker-managed firms and conventional firms has been mainly concerned with employment and wages adjustments, productivity and business cycle determinants of entry and exit. ${ }^{1}$ While there is some evidence on the effect of unions and employee stock ownership plans (ESOPs) on firm survivability, this is to my knowledge one of the first studies on firm survival comparing conventional firms and firms

\footnotetext{
${ }^{1}$ Craig and Pencavel (1992; 1995), Doucouliagos (1995), Pencavel et al (2006), Pérotin (2006), Burdín and Dean (2009) and Fakhfakh et al (2012).
} 
fully controlled by their workforce. In contrast to previous descriptive research on workermanaged firms' survivability, I rely on appropriate micro data for both types of firms and apply a broad range of survival analysis techniques. The analysis of worker-managed firms, the most radical implementation of workplace democracy and profit-sharing, may also shed light on the potential effects of more limited participatory initiatives at the firm level. Thus, this paper also contributes to the growing body of recent literature on shared capitalism. $^{2}$

\section{Theoretical literature and previous evidence}

According to Dow (2003), any theoretical explanation concerning the paucity of WMFs actual economies should rely on the identification of relevant physical and institutional asymmetries between capital and labor. The author points out that differences in alienability may determine why ultimate control rights over firms are usually assigned to capital suppliers. The author points out that while human capital is not alienable, the ownership of non-human assets can be transferred from one person to another. Dow identifies three types of asymmetries that may be important to account for different survival prospects of WMFs compared with CFs.

First, there are commodification asymmetries involving the ability of members to trade control positions in markets (Dow, 2003, p236). In a conventional firm, shares of stock conferring voting rights can be transferred from one person to another without changing firm's physical assets. By contrast, it is impossible to transfer control rights in a WMF without replacing one person by another in the labor process. An adverse selection problem arises in this context because a departing member might benefit by selling her position to an undesirable replacement, inflicting losses on stayers (Dow and Putterman, 2000). This is one potential explanation of why membership markets are rare and, hence, why assets in WMFs are usually owned by their workforce collectively. Under collective ownership, WMFs would make inefficient employment and investment decisions which in turn may

\footnotetext{
${ }^{2}$ See, for instance, Kruse et al (2010).
} 
negatively affect their survival chances compared with conventional firms (Ward, 1958; Furubotn, 1976).

In relation to employment decisions, the basic neoclassical model predicts that WMFs would not respond in the usual way to changes in the product price; instead, they would reduce the level of employment and output when the market price increases (Ward, 1958). The model assumes that WMFs maximizes revenue per worker rather than total profits. The theoretical foundations of this seminal model have been harshly criticized in the literature and the backward supply response of WMFs has not been empirically confirmed. ${ }^{3}$ However, there is ample evidence that employment responses to demand shocks are less elastic in WMFs compared with conventional firms (Craig and Pencavel, 1992; Pencavel et al, 2006; Burdín and Dean, 2009). Employment smoothing may be costly for WMFs, specially in industries in which employment variability is high, even though it may also provide incentives for investments in training and firm-specific human capital (Levine and Parkin, 1994). Regarding investment decisions, WMFs would suffer from the so-called horizon problem (Furubotn, 1976). As worker-members have no claim on future investments' returns after separation from their firm, the evaluation of investment projects will be truncated to the members' expected employment horizon. Workers would prefer to distribute income in the current period instead of financing investments, unless the expected rate of return exceeds the workers' opportunity cost of the funds by an amount that depends inversely on their expected tenure within the firm (Gui, 1984). Therefore, WMFs would underinvest and would only carry out projects with short-run returns. Moreover, members of a WMF must supply financial resources as well as labor and, hence, they would invest their savings in an asset whose returns are highly correlated with the returns on their human capital. But this would be incompatible with the desire of riskaverse workers to maintain a diversified financial portfolio (Dow and Putterman, 2000).

\footnotetext{
${ }^{3}$ This result does not necessarily hold in the case of multiproduct WMFs or when the production process involves other variable inputs apart from labor. It has also been argued that worker-members will be reluctant to vote for layoffs because in a WMF in which members are equally treated everybody faces similar probabilities of being selected for expulsion (Moene, 1989).
} 
It is worth noticing that the underinvestment critique was originally directed to labor managed firms in which, as in the old Yugoslav system, worker-members receive a share of current profits but do not have an ownership stake. ${ }^{4}$ The applicability of the theory to WMFs operating in Western market economies depends on the structure of property rights (Bonin et al, 1993). Physical assets of WMFs can be owned by their members collectively or individually. Under collective ownership members do not own tradable shares and enjoy the right to usufruct as long as they work in the firm. Under individual ownership, members own capital shares that vary with the value of the firm (Ben Ner, 1988a). The underinvestment critique applies to collectively owned WMFs, as it is the case of most Uruguayan WMFs, but not to those owned through individual shares. In the latter case, departing members are able to capture the expected value of future profits based on current investments and recoup their past contributions toward such investments by selling their shares (Dow, 1986). However, as mentioned, membership markets are rarely observed in practice $^{5}$

Second, there are commitment asymmetries concerning the capacity of firm controllers to extend credible commitments to the suppliers of non-controlling factors. Dow argues that while giving control rights to the workforce facilitates the alignment of workers' incentives within the firm, it also makes more difficult to offer credible guarantees of repayment to investors (see also Bowles and Gintis, 1994). As in WMFs the conflict of interest between managers and workers is virtually eliminated, this type of firms would reduce supervision costs and elicit higher levels of effort through the combination of profit sharing and mutual monitoring among coworkers, overcoming the standard free-rider problem associated with team production (Alchian and Demsetz, 1972). ${ }^{6}$ However, WMFs would face a disadvantage to attract capital as members may not act in the interest of the lender. They may decide to pay high wages, misuse the capital equipment or engage in risky projects. According to Dow, the net effect of these commitment problems is to bias the allocation of

\footnotetext{
${ }^{4}$ Estrin and Uvalic (2008) discuss the underinvestment critique in the context of the Yugoslav system.

${ }^{5}$ There is also evidence that existing membership markets operate imperfectly as share prices seem to be systematically undervalued (Craig and Pencavel, 1992).

${ }^{6}$ Available empirical evidence generally indicate that worker cooperatives do not underperform conventional firms in terms of productivity (Craig and Pencavel, 1995; Jones, 2007; Fakhfakh et at, 2012; Pencavel, 2012).
} 
control rights over firms against labor. While capitalist firms develop social conventions that would make the workplace conflict tolerable, WMFs - mainly composed by wealthconstrained workers- would have limited access to capital markets.

Finally, there are also composition asymmetries, involving disparities in the characteristics of control groups, such as their size or the degree of heterogeneity in members' preferences. The problems faced by WMFs with an heterogeneous workforce have been pointed out notably by Hansmann (1996). WMFs may face higher costs of collective-decision making associated with democratic governance compared with conventional organizations. While capital suppliers unanimously support the maximization of profit, workers may have widely different attitudes toward effort, investment decisions, wage levels, job security and other workplace amenities. ${ }^{7}$ For instance, it has been argued that WMFs may suffer from excessive egalitarianism which in turn may cause the outflow of high ability workers (Gui, 1987; Kremer, 1997; Abramitzky, 2008). ${ }^{8}$ There is empirical support for the idea that the presence of skilled labor has a positive and significant effect on firm survival (Gimeno et al, 1997; Mata and Portugal, 2002; Geroski et al, 2010). Hence, the inability of WMFs to retain skilled labor may negatively affect their survival chances compared with conventional firms. ${ }^{9}$

Compared to the extensive theoretical literature, empirical work studying the relationship between workers' control and firm survival is very uncommon. Previous studies on WMFs survival have usually lacked appropriate microdata for both types of firms and relied on aggregate descriptive comparisons (Pérotin, 1987; Ben-Ner, 1988b; Staber, 1989; Pérotin, 2004). Close to the empirical approach adopted in this paper, Park et al (2004) studied the effect of employee ownership plans (ESOPs) on firm survival, relying on data from U.S. public companies and estimating a Weibull model. The study found that employee

\footnotetext{
${ }^{7}$ Conventional investors may have different time horizons and time preference rates and these may also result in collective choice problems regarding investment decisions in capitalist firms (Pencavel, 2012).

${ }^{8}$ Indeed, survey evidence indicates that WMFs usually have a more compressed wage structure than conventional firms (see, for instance, Bartlett et al, 1992).

${ }^{9}$ Inequality may be detrimental for firm performance if it increases perceptions of unfairness among workers and deters cooperation in the workplace (Akerlof and Yellen, 1990; Levine, 1991; Baron and Pfeffer 1994).
} 
ownership increases the probability of firm survival. ${ }^{10}$ The author suggested that the higher survival may be explained by the greater employment stability exhibited by these companies. $^{11}$

\section{Worker-managed firms in Uruguay}

In Uruguay, WMFs are defined as firms legally registered as Producer Cooperatives in which the ratio between permanent employees and members does not exceed 20\%. Despite the fact that WMFs are allowed to hire temporary employees in response to seasonal demand changes, they must fulfill this maximum level of hired workers to be entitled with certain tax advantages. In particular, WMFs are exempted from paying the employer payroll tax to social security. Finally, the law defines a minimum of six members in order to register a new cooperative firm.

Even though certain key organizational features are predetermined by law, WMFs are free to decide upon a broad range of associational rules. Regarding their governance structure, WMFs have a General Worker Assembly that selects a Council (who usually selects the managers) to supervise the daily operations. Each member within the assembly has only one vote, regardless of her capital contribution to the firm. Uruguayan WMFs mainly operate under a collective ownership regime. As is common in other countries, membership markets are extremely rare in Uruguay. Recent survey evidence indicates that less than $10 \%$ of Uruguayan WMFs are owned by their workforce through individual shares (Alves et al, 2012). WMFs usually use two sources to finance their activities: bank loans and retained earnings. As capital markets play a minimal role in the financing and capitalization of Uruguayan firms, most conventional firms operate as closely held firms.

\footnotetext{
${ }^{10}$ A related strand of research analyzes the relationship between unionization and closures (Freeman and Kleiner, 1999; Bryson, 2004; DiNardo and Lee, 2004).

${ }^{11}$ Park et al (2004) identified employee-owned firms as those in which workers own 5\% or more stock of the company. This raises the concern about the limited scope of workers' control in most of these companies.
} 
Previous studies have shown that Uruguayan WMFs exhibit a different adjustment process of wage and employment levels compared with conventional firms. The employment responses to idiosyncratic and macroeconomic shocks seem to be less elastic in WMFs than in conventional firms (Burdín and Dean, 2009; 2012).

\section{Data and descriptive statistics}

This study is performed using an unbalanced panel of Uruguayan firms, consisting of monthly firm-level observations over the period January 1997- July 2009. The data set is based on social security administrative records provided by Banco de Previsión Social (BPS), the public agency in charge of social security affairs in Uruguay. The data set covers the entire population of firms registered as Producer Cooperatives (PCs) and conventional firms in 112 3-digit sectors in which at least one PC was registered during that period. The available firm-level information includes firms' industry class (5 digits, ISIC, fourth revision), employment, and average wage, distinguishing members and non-members in the case of PCs. The analysis is based on all cohorts of newly formed firms since February 1997 onwards. I do not consider firms that were already active at the beginning of the observation period (January 1997) as their spells are left-censored, i.e. there is no information on their starting dates. ${ }^{12}$

Previous studies on Uruguayan WMFs have pointed out that not all firms registered as PCs should be considered as WMFs. Specifically, in many firms legally registered as PCs the majority of the workforce has no control over firm decisions as in conventional firms (Burdín and Dean, 2009; 2012). I distinguish WMFs from the total population of producer cooperatives using information of the ratio between employees and members. I define WMFs as those firms registered as PCs in which this ratio is no greater than $20 \%$ (measured at the time of entry). I drop observations on producer cooperatives in which the computed employee-to-member ratio is greater than $20 \%$.

\footnotetext{
${ }^{12}$ Left-censored firms have already been exposed to the risk of failure for an unknown amount of time before coming under observation.
} 
Regarding the identification of firms' failures, I proceed in the following manner. All private Uruguayan firms must transfer employees' social security contributions; when a new firm is registered as active in BPS files, an entry can be identified in the data, while a firm cancellation indicates it is no longer active as such (i.e., a "failure"). Hence, the date of entry and exit of each firm can be determined accurately. "Failure" is a dummy variable which takes value 1 (at the exit date) if the firm exits during the period and 0 otherwise.

The way in which failures are identified in the data requires two further clarifications. First, information regarding the reason for dissolution is not available. This is a potential limitation as cases of successful firms dissolved from being bought out by another firm may be counted as failures. Specifically, it is not possible to identify mergers and acquisitions. However, anecdotal evidence suggests that a negligible fraction of dissolutions seems to be explained for these reasons. ${ }^{14}$

Second, a broader definition of organizational failure may not only include dissolutions but also transformations of one organizational type into another type (Ben-Ner, 1988a). For instance, workers may buy out a CF in financial distress and convert it into a WMF in order to prevent the firm from shutting its doors. Conversions of CFs into WMFs cannot be identified in the data. However, survey evidence indicates that most Uruguayan WMFs were created from scratch. Only $11 \%$ of total PCs that were active in 2009 had been formed through conversions of conventional firms (Alves et al, 2012). In addition, it has been argued that successful WMFs may degenerate into CFs increasing the employee-to-member ratio over time (Ben-Ner, 1984). Considering the impossibility of providing a unified treatment of conversions in both CFs and WMFs, cases of WMFs that increase their employee-to-member ratio surpassing the initial threshold of $20 \%$ over the course of their

\footnotetext{
${ }^{13}$ Audretsch et al (1999) investigated the relationship between start up size and firm survival also using social security records from Italy.

${ }^{14}$ There are no official statistics on merges and acquisitions in Uruguay. The firms are obliged to inform mergers and acquisitions to the Commission for the Promotion and Defense of Competition (Ministry of Economy and Finance) only in cases in which such operations involve substantial changes in the market structure. For instance, the commission received only eleven notifications of mergers and acquisitions during the period 2009-2011.
} 
life were not computed as failures. ${ }^{15}$ Hence, the definition of "failure" used in the analysis only refers to dissolutions.

The basic information on the firm-level panel for the final sample is reported in Appendix Table A1. There are 29125 different firms, including 223 WMFs (i.e. 1\% of total firms in the sample and $74 \%$ of total firms registered as PCs). As the average number of monthly records per firm is 43.21 , the total number of firm-month observations in the data is 1258606. There are approximately $15 \%$ of firms with time gaps (interval truncation) and the median gap length is 5 months. A gap in a firm's spell may be due to temporal interruption of operations or to the fact that the firm exits and restarts with the same identification number. The social security agency keeps the original identification in both cases. Temporal exits from the panel are not computed as failures. The number of firms' failures is 15308, including 90 failures of WMFs. The average failure rate is lower in WMFs $(40.4 \%)$ than in CFs $(53 \%)$.

Table 1 reports information on the characteristics of both types of firms. Firm start-up size is larger in WMFs than in CFs. While most CFs (84\%) are classified as micro-enterprises (less than 6 workers), WMFs $(63 \%)$ are typically small firms (between 6 and 18 workers). ${ }^{16}$ This is due to the fact that the Uruguayan law determines that WMFs cannot be formed with less than six members. WMFs are highly concentrated in Services (49\%) and CFs are more frequently located in Manufacturing, Transport and Other Sectors (Construction, Electricity and Retail Trade). The average firm wage at the entry date is higher in CFs than in WMFs.

\section{$\{\{$ Place Table 1 about here $\}\}$}

As expected, the comparison between dying and surviving firms indicates that survival is positively associated with employment and wage growth in both WMFs and CFs (see

\footnotetext{
${ }^{15}$ Below, I analyze the sensitivity of the results to the inclusion of this group of WMFs.
} 
Appendix Table A2). This suggests that firm survival is associated with better firm performance no matter whether the dissolution decision is controlled by the workforce or by conventional investors. Interestingly, firm survival seems to be negatively correlated with both wage and employment variability. WMFs exhibit significantly less employment variability, more wage volatility and experience higher wage growth and lower employment growth rates than CFs. A similar pattern arises when microenterprises are excluded, except from the fact that the differences in terms of employment growth reverse in favor of WMFs. As mentioned, the Uruguayan law defines a minimum of six members in order to start-up a WMF. Hence, the higher employment growth rates of CFs compared to WMFs, when the whole sample is considered, may simply reflect a composition effect associated with the fact that firm's growth is inversely related with start-up size (see, for instance, Audretsch et al, 1999). However, among those firms that do not fail employment grow faster in CFs than in WMFs.

The descriptive analysis of the comparative demographic behavior of WMFs and CFs shows interesting results. Birth and exit rates of WMFs and CFs during this period are presented in the Appendix Figure A1 and A2. The average birth and exit rate for WMFs is $10 \%$ and $7 \%$ respectively. In the case of CFs, $11 \%$ of firms enter and $11 \%$ of firms exit the market in a given year (when microenterprises are excluded the average birth and exit rates are $5.5 \%$ and $7.5 \%$ in that order). Figure 1 reports non-parametric estimates of the survivor and hazard function, pooling all cohorts of newly formed firms during the period 19972009. At first glance, WMFs seem to have a lower hazard rate than CFs. According to the Log-rank test, I reject the null hypothesis of equality of the survivor functions $\left(\chi_{(1)}=10.1\right) .{ }^{17}$ The hazard exhibits an inverted U-shape for both WMFs and CFs, reaching a maximum around the second year of the firm lifespan and then decreasing with firm age. The pattern of greater vulnerability of young firms observed in the data seems consistent with the "liability of newness" argument developed in the organizational ecology and

16 This right-skewed size distribution is characteristic of Uruguayan firms. For instance, data from the National Statistical Institute indicate that $83 \%$ of Uruguayan firms employed less than 5 workers in 2010 (www.ine.gub.uy).

${ }^{17}$ Burdín and Dean (2010) obtained similar results comparing non parametric estimates of the hazard of exit for Uruguayan WMFs and CFs over the period 1996-2005. 
industrial organizational literature on firm survival (Jovanovic, 1982; Freeman et al, 1983; Geroski, 1995). ${ }^{18}$

\section{$\{\{$ Place Figure 1 about here $\}\}$}

Figure 2 provides further exploratory analysis of the data, reporting the survivor functions by cohorts of firms and sectors. WMFs do not seem to underperform CFs in any cohort. Indeed, WMFs exhibit better performance than CFs in most cohorts, particularly when the comparison is restricted to Retail Trade and Services. However, one should be caution to draw definitive conclusions from these graphs for two reasons. First, non-parametric estimates do not account for other factors that may affect firm survival. Second, given the small number of total WMFs, cohort-sector specific survivor functions are rather imprecisely estimate. For these reasons, I provide in the next sections a more rigorous econometric test of the differences in survivability between WMFs and CFs, estimating semi-parametric and parametric duration models.

\section{$\{\{$ Place Figure 2 about here $\}\}$}

\section{Econometric framework}

The variable of interest in the analysis of firm survival is the time elapsed between entry and exit. ${ }^{19}$ The lifespan of each firm either can be fully observed (complete spell) or rightcensored (incomplete spell). It is assumed that the length of this spell $t>0$ is the realization of a random variable $T$ with a cumulative distribution function (cdf) and probability distribution function (pdf) given by $F(t)$ and $f(t)$ respectively. $F(t)$ is also known as the failure function. The survivor function is defined as $S(t) \equiv 1-F(t)$ and

\footnotetext{
18 The "liability of newness" refers to the higher risk of failure faced by younger firms (Stinchcombe, 1965).

${ }^{19}$ This section draws on Jenkins (2005).
} 
represents the probability of surviving beyond time $t .^{20}$ The pdf is the slope of the failure function such that, $f(t)=\lim _{\Delta \rightarrow 0} \frac{P(t \leq T \leq t+\Delta t)}{\Delta t}=\frac{\partial F(t)}{\partial t}=-\frac{\partial S(t)}{\partial t}$.

The survivor function $S(t)$ and the failure function $F(t)$ both satisfy the properties of probabilities. $S(t)$ is bounded between zero and one and is strictly decreasing in $t, S(t)$ is equal to one at the beginning of the spell and zero at infinity. The hazard rate, $h(t)$, is defined as the instantaneous chance of failure at time $t$. More precisely, it is the conditional probability that the firm exits the market at time $t$, conditional on the fact that the firm has been active until $t$, such that $h(t)=\frac{f(t)}{1-F(t)}=\frac{f(t)}{S(t)}$. Finally, the cumulative hazard rate, $H(t)$, is defined as the integral of the hazard rates over $(0, \mathrm{t})$, such that $H(t) \equiv \int_{0}^{t} h(u) d u .^{21}$

The shape of the hazard function is in principle unknown so it is necessary to impose distributional assumptions on the data. To avoid misspecification errors, I estimate a Cox proportional hazard model. This model, originally proposed by Cox (1972), has been widely used in the literature on firm survival (for a review see Manjón and Arauzo, 2008). The main advantage of this model relies on the fact that it is possible to estimate the relationship between the hazard rate and the covariates without making assumptions about the functional form of the baseline hazard. The Cox model is specified as follows:

$$
h(t \mid .)=h_{0}(t) \exp \left(\beta_{1} C O O P_{i}+\beta_{2} X_{i}\right)
$$

where $h_{0}(t)$ is the baseline hazard function, COOP is a dummy variable that takes value equal to one if the firm is a WMF and $\mathrm{X}$ is a vector of control variables (firm size and average wage at the entry date, cohort dummies, industry dummies). The coefficient of

\footnotetext{
20 More precisely, $P(T \leq t)=F(t)$, which implies for the survivor function that $P(T>t)=1-F(t) \equiv S(t)$.

${ }^{21}$ The only restriction on the hazard rate is that $h(t) \geq 0$. Note that $H(t) \geq 0$ and $\partial H(t) / \partial t=h(t)$.
} 
interest is $\beta_{1}$. The effect of a unit change in a covariate is to produce a constant proportional change in the hazard rate, i.e. the proportional hazard assumption.

\section{Results}

Table 2 reports the estimates of the baseline Cox-model. In Column (1), the estimation only control for firm's start-up size and average wage. More precisely, estimates include the log of employment at the time of entry. ${ }^{22}$ The firm average wage at the entry date is included as a rough proxy of the starting firm quality. For instance, the average wage may reflect the initial endowment of human capital within the firm. In Column (2), the estimates include 4 industry dummies in order to control for time-constant industry characteristics.

It has been argued that the environment at the time of birth largely determines the strategic choices of firms. Organizations founded in unfavorable times are unlikely to be close to their optimal structural configuration and may not be able to find the right kind of resources, make the correct organization specific investments, or design appropriate organizational routines (Geroski et al, 2010). Furthermore, entrepreneurs who have entered self employment from unemployment exhibit higher exit rates than those who have entered from paid employment (Pfeiffer and Reize, 2000). Indeed, there is evidence pointing out that if the underlying motivation to start a new firm is linked to innovative projects, then better post-entry performance may be expected than if a new firm is started on the basis of a purely "defensive" motivation, such as the fear of becoming unemployed (Vivarelli and Audretsch, 1998; Santarelli and Vivarelli, 2007). The effect of founding conditions may be important in this setting as it is well known that WMFs exhibit higher formation rates in recessions (Pérotin, 2006). Therefore, in Column (3) estimates also include 12 cohort dummies in order to control for macroeconomic conditions at the time of entry. ${ }^{23}$

\footnotetext{
${ }^{22}$ Small firms may operate at a sub-optimal scale level of output and face a cost disadvantage with respect to larger firms (Caves, 1998; Geroski, 1995; Audretsch and Mahmood 1995, Mata and Portugal 1994; Esteve et al, 2004).

${ }^{23}$ The inclusion of cohort dummies also ensures that the assumption that the true duration is independent of the starting and censoring time holds (Wooldridge, 2001: p696).
} 
Results indicate that WMFs exhibit higher survival chances than capitalist firms and the difference is highly significant in all specifications. According to estimates reported in Column (3) of Table 2, the hazard of dissolution is about $25 \%$ lower for WMFs than for CFs. ${ }^{24}$ The included control variables have the expected effect. In line with the large IO literature on firm survival, there is a negative and significant relationship between initial firm's size and the hazard of exit. Moreover, survival prospects are positively associated with the firm average wage at the time of entry. The estimated hazard function - obtained from the Cox regression- is plotted in the Appendix Figure A4.

\section{$\{\{$ Place Table 2 about here $\}\}$}

To check the sensitivity of the results, alternative estimates were performed including year fixed effects to control for current macroeconomic conditions. I also estimated the model including four start-up size categories (distinguishing micro, small, medium and large firms) and 66 2-digit industry dummies and analyze whether the results are affected by the exclusion of firms with time gaps in their records. Finally, to check whether the result is driven by the way in which I identified WMFs, I estimated the model comparing conventional firms with all firms registered as PCs. Neither of these modifications alter the results. $^{25}$

The observed difference between WMFs and CFs may simply reflect industry differences in demand volatility. To rule out this possibility, Column (1) of Table 3 presents the results of additional estimates of the baseline Cox model, excluding construction and retail trade firms. ${ }^{26}$ I exclude these sectors because the presence of WMFs is comparatively low. The results are very similar compared with baseline estimates. Even excluding firms located in

\footnotetext{
${ }^{24}$ I check the empirical plausibility of the proportional hazard assumption by means of graphical methods (Cleves et al, 2008). This assumption seems to be satisfied by the data (see Appendix Figure A3). According to the test based on the Schoenfeld residuals for the variable Coop, I do not reject the proportional hazard $(\mathrm{PH})$ assumption. However, the $\mathrm{PH}$ assumption is rejected when the global test of the model is considered (Appendix Table A3). For this reason, in the next section I analyze the sensitivity of the results providing additional estimates of parametric models that do not rely on the PH assumption.

${ }^{25}$ All these additional estimates are available from the author upon request.

${ }^{26}$ It is worth mentioning that during this period the Uruguayan law forbade the formation of WMFs in Retail Trade.
} 
high firm turnover sectors, the hazard of exit is $24 \%$ lower for WMFs than for CFs (exp(0.272)-1). In Column (2)-(4) of Table 3, I report the results of separate estimates for Manufacturing, Transport and Services. While in Manufacturing and Transport the hazard of exit is not significantly different, in the Service sector the hazard of exit of WMFs is $46 \%$ lower compared with CFs (exp(-0.619)-1). Thus, the better performance of WMFs in the Service sector explains the aggregate results obtained in the baseline estimates. This is consistent with fact that firms in the services sector have lower physical capital requirements compared to other sectors. According to theoretical explanations previously discussed, this is precisely the kind of economic environment in which one would expect that WMFs outperform conventional firms (see, for instance, Bowles and Gintis, 1994; Dow, 2003).

\section{$\{\{$ Place Table 3 about here $\}\}$}

\section{Robustness checks}

I performed a large number of robustness checks, addressing the following issues: i) differences in the size composition of both types of firms, ii) conversions of WMFs into CFs, iii) differences in tax regimes, iv) unobserved heterogeneity and alternative parametric specifications of the hazard function. All of these estimates are presented in Columns (1)(6) of Table 4.

\subsection{Size composition}

One important concern regarding the estimates presented in the previous section refers to the different size composition of both groups of firms. As explained, the Uruguayan law establishes that WMFs must be formed with at least six workers. This formal rule seems to be enforced reasonably well: on average only $18 \%$ of WMFs can be defined as microenterprises. By contrast, 85\% of CFs start-up with less than six workers (see Table 1). It is a stylized fact in the literature on firm survival that survival chances positively depend on

firm size (Caves, 1998; Audretsch and Mahmood; 1994; Bartelsman et al., 2005). Therefore, results presented in the previous section may be an artifact of the different size 
composition of both types of firms. Column (1) of Table 4 reports the estimates of the Cox model excluding micro-enterprises. ${ }^{27}$ It is worth considering that in this case estimates are performed with 201877 observations (i.e. 16\% of the original sample). Despite this dramatic loss of information, results remain qualitatively unchanged. WMFs exhibit higher survival chances than CFs even excluding microenterprises. I continue restricting estimates to firms employing at least six workers at the time of entry through out the rest of the analysis.

\subsection{Degeneration}

WMFs were identified in the data as those firms registered as PCs in which the employeeto member ratio was no greater than $20 \%$ at the time of entry. This implies that previous estimates may be pooling WMFs in which the employee-to-member ratio evolved very differently, including cases of WMFs in which the ratio surpass the initial threshold of $20 \%$ at some point in time. It is worth noticing that hired workers in WMFs, similarly to what occur in CFs, do not have formal control rights over the organization, which means that the higher the fraction of employees the lower the proportion of the workforce involved in decision-making within the firm. One could argue that in such cases WMFs have survived longer but at the expense of degenerating into CFs (Ben-Ner, 1984). ${ }^{28}$ However, it is doubtful whether a WMF that surpass the $20 \%$ threshold in a given month can be considered a case of organizational transformation as the law allows WMFs to exceed the threshold temporarily to cope with seasonal demand increases. A better approximation is to define conversions of WMFs into CFs as those WMFs in which the employee-to-member ratio averaged during their entire spells exceeds 20\%. Column (2) of Table 4 reports additional estimates excluding those cases. Results remain qualitatively unchanged. Workers' control is positively associated with firm survival, even excluding that group of WMFs.

\footnotetext{
${ }^{27}$ As reported in Table 1, the size composition of WMFs and CFs becomes rather similar after the exclusion of microenterprises.

${ }^{28}$ Burdín and Dean (2009) did not find support for the degeneration hypothesis in the Uruguayan case.
} 


\subsection{Differences in tax regimes}

As in most countries, WMFs in Uruguay benefit from a favorable tax treatment. Specifically, they are exempted from paying the employer payroll tax (i.e. employer contributions to the pension system) for the fraction of the wage bill corresponding to members (this exemption does not hold for hired workers). ${ }^{29}$ In fact, as reported in Table 1, this implies that WMFs face a lower effective tax burden than CFs. One may argue that the superior performance WMFs in terms of survivability is simply a by-product of this favorable tax regime. Interestingly, during this period there was considerable variability in payroll tax rates applied to CFs across industries and over time, including sub-periods of zero tax rate in specific sectors (Manufacturing, Transport). In addition, the Uruguayan Constitution establishes further tax exemptions in sectors in which WMFs and conventional firms compete, such as in the provision of educational services. Hence, CFs also enjoy full or partial tax exemptions in many sectors during the period of analysis (Bucheli and Vigna, 2006). ${ }^{30}$

Using the information on the 5-digit industry classification and the wage bill of each firm (distinguishing members and employees in WMFs), I construct a measure of the effective tax burden faced by each firm over time. I define the effective tax rate faced by firm $i$ at time $t$ as the total payroll tax bill divided by the total wage bill and, hence, given by $T_{i t}=\frac{\text { Taxbill }_{i t}}{W_{i t}}$. This variable intends to control for differences in non-wage labor costs faced by both types of firms. Results are presented in Column (3) of Table 4. The effect of the effective tax burden on the hazard of exit is significantly positive, though rather small. One percentage point increases in the tax burden increases the hazard by $3 \%$. The condition of being a WMF still has a negative effect on the hazard compared with CFs. The magnitude of the effect is smaller compared to estimates reported in Column (1) of Table 4: the hazard rate is about $29 \%$ lower for WMFs than for CFs.

\footnotetext{
${ }^{29}$ Uruguayan WMFs are also fully exempted from the corporate income tax (IRAE). However, the corporate tax rate is quite low in Uruguay $(25 \%)$. Available estimates indicate that the corporate income tax represents on average $1 \%$ of firm revenue in Uurguay (Gonzalez and Montero, 2008).

${ }^{30}$ Table A4 (Appendix) provides a detailed description of the evolution of tax rates by sectors between 1997 and 2009.
} 


\subsection{Unobserved heterogeneity and parametric specification of the hazard}

The Cox model allows to estimate the effect of covariates without making assumptions about the pattern of duration dependence of the hazard. Although this procedure minimizes specification errors, it produces less efficient estimates compared to the "correct" parametric model. Moreover, previous estimates have assumed that all differences between firms are captured by observed explanatory variables. This may bias coefficient's estimates and overestimate the negative duration dependence of the hazard function, i.e., the duration dependence of the hazard may be less negative when unobserved heterogeneity is present (Jenkins, 2005). Therefore, I consider a generalization to allow for unobserved firmspecific effects ("frailty"). A frailty model defines the hazard to be ${ }^{31}$ :

$$
h\left(t_{i} \mid x_{i}, \alpha_{i}\right)=\alpha_{i} h\left(t_{i} \mid x_{i}\right)
$$

where $\alpha_{i}$ is some unobserved-observation specific effect. The effect $\alpha_{i}$ is known as frailty and indicates that firms are heterogeneous due to factors that remain unobserved. It is assumed that $\alpha_{i}$ has mean one and variance $\theta$, where $\theta$ is estimated from the data. The relationship between the hazard and survivor function is such that

$$
S\left(t_{i} \mid x_{i}, \alpha_{i}\right)=\left\{S\left(t_{i} \mid x_{i}\right)\right\}^{\alpha_{i}}
$$

where $S\left(t_{i} \mid x_{i}\right)$ is the survival function for a standard parametric model. The unconditional survival function is obtained by integrating the unobservable $\alpha_{i}$. Assuming that $\alpha_{i}$ follows a gamma distribution and has a pdf $g\left(\alpha_{i}\right)$, then the unconditional survivor function is such that

$$
S_{\theta}\left(t_{i} \mid x_{i}\right)=\int_{0}^{\infty}\left\{S\left(t_{i} \mid x_{i}\right)\right\}^{\alpha_{i}} g\left(\alpha_{i}\right) d \alpha_{i}
$$

\footnotetext{
${ }^{31}$ The formal exposition draws heavily on Cleves et al (2008).
} 
where,

$$
g\left(\alpha_{i}\right)=\frac{\alpha_{i}^{1 / \theta-1} \exp \left(-\alpha_{i} / \theta\right)}{\Gamma(1 / \theta) \theta^{1 / \theta}}
$$

Finally, combining (4) and (5), the following expression is obtained:

$$
S_{\theta}\left(t_{i} \mid x_{i}\right)=\left[1-\theta \ln \left\{S\left(t_{i} \mid x_{i}\right)\right\}^{\alpha_{i}}\right]^{-1 / \theta}
$$

The frailty model is the standard parametric model with the addition of one new parameter, $\theta .^{32}$ Assuming a Weibull distribution of the hazard with gamma-distributed heterogeneity, the survivor function can be written as follows:

$$
\left.S_{\theta}\left(t_{i} \mid x_{i}\right)=\left[1-\theta \exp \left(\beta_{0}+x_{j} \beta_{x}\right) t_{j}^{p}\right)\right]^{-1 / \theta}
$$

Estimates of this model are reported in Column (4) of Table 4. Results remain unchanged: WMFs exhibit a lower hazard than CFs. ${ }^{33}$ The estimated parameter $1<\hat{p}<2$ in the Weibull model indicates that the hazard is increasing over time at a decreasing rate. ${ }^{34}$ This pattern of duration dependence is not consistent with the shape of the hazard reported in Figure 1. Considering the potential misspecification of the hazard, Column (5) reports the estimates of the frailty model assuming a log-logistic distribution of the hazard. Results are qualitatively similar. The status of WMF is positively associated with longer survival times. $^{35}$ As the estimated parameter $\hat{\gamma}<1$, the log-logistic hazard increases and then decreases which in turn is consistent with the inverted U-shaped pattern described by Figure 1.

\footnotetext{
${ }^{32}$ It is worth noting that $S_{\theta}\left(t_{i} \mid x_{i}\right)$ reduces to $S\left(t_{i} \mid x_{i}\right)$ as $\theta$ goes to zero.

${ }^{33}$ The Wald test for $H_{0}: \ln (p)=0$ for which the test statistic is 8.98 leads to rejection of the null hypothesis of constant hazard.

${ }^{34}$ The $95 \%$ confidence interval for $\hat{p}$ is (1.239 1.397).

${ }^{35}$ The log-logistic model has no Proportional Hazard interpretation as it is defined in the Accelerated Failure Time (AFT) metric. The effect of the covariates must be interpreted in terms of survival time and not in terms of the hazard. Therefore, the magnitude of the effect cannot be compared with Cox model estimates.
} 
Finally, Column (6) of Table 4 presents the estimates of a Generalized Gamma Model. ${ }^{36}$ Apart from the coefficient $\beta$, this model involves the estimation of two additional parameters, $\kappa$ and $\sigma$. The gamma model presents two main advantages. First, this model possesses a highly flexible hazard function, allowing a large number of possible shapes. Second, this distribution includes as special cases the Weibull model $(\kappa=1)$, the Exponential model $(\kappa=1, \sigma=1)$ and Log-Normal model $(\kappa=0)$. The fact that these parametric models are nested allows the use of the Gamma model for searching the appropriate parametric specification for the data. The estimate indicates that the status of WMF has a positive effect on survival time. The estimate of the coefficient of interest $\hat{\beta}^{\text {COOP }}=0.545$ indicates that the status of WMF increases the expected value of $\ln (t)$ by 0.545 , i.e. for a firm predicted to fail at $t=1$, the status of WMF would delay the predicted time of failure to $\exp \{\ln (1)+0.545\}=1.725$.

The Wald test for $H_{0}: \kappa=1$ leads to a strong rejection of the Weibull model $\left(\chi_{(1)}=185.59\right)$. The result of the Wald test for $H_{0}: \kappa=1, \sigma=1$ also allows to discard the Exponential model $\left(\chi_{(1)}=260.35\right)$, suggesting that the hazard is not constant over time. The $95 \%$ confidence interval for $\hat{\kappa}$ is $(-0.1110 .169)$ which indicates that $H_{0}: \kappa=0$ is not rejected. This means that a log-normal model would provide similar estimates to the Gamma model. ${ }^{37}$

\section{$\{\{$ Place Table 4 about here $\}\}$}

\section{Exploring possible explanations}

The results presented in the previous sections are surprising considering several theoretical predictions suggesting that WMFs will have lower survival chances than conventional

\footnotetext{
36 The Gamma model is also defined in the AFT metric.

${ }^{37}$ In fact, the Log-Normal model gives the highest Akaike Information Criterion (AIC) index which suggests its selection among several parametric models (Appendix Table A5).
} 
firms. In this section, I evaluate the relevance of different explanations that may account for the previous findings. ${ }^{38}$

The greater survival of WMFs may simply reflect the fact that worker-members exert control over the dissolution decision, particularly when outside job opportunities are scarce. Members may be more reluctant to close than conventional investors and decide to continue running the firm just in order to secure their jobs. It is doubtful whether the greater survival of WMFs can be interpreted as a measure of firm performance in this case. From a social point of view, it might be better to dissolve the firm and reallocate labor and physical assets to more productive firms. In fact, the period analyzed in this paper includes four years (1999-2002) in which Uruguay faced a deep economic crisis. This may partly explain the large difference in survival prospects in favor of WMFs found in the previous sections.

To rule out this explanation, I split the analysis in two four-year sub-periods characterized by very different macroeconomic conditions and perform separate survival estimates for each period. During the period 1999-2002, the Uruguay experienced a severe economic crisis. The average GDP growth rate was $-3.7 \%$ and the unemployment rate rose to $17 \%$ in 2002. By contrast, between 2004 and 2007 the Uruguayan economy performed extremely well, the GDP grew on average 5.8\% and the unemployment rate decreased to $9.6 \%$ in 2007. The average unemployment rate was 2.7 percentage points lower compared to the period 1999-2002 (see Appendix Table A6).

Table 5 reports the results of separate estimates for the two periods of a parametric survival model that assumes an exponential distribution of the baseline hazard. ${ }^{39}$ If the greater survival of WMFs is mainly driven by the lack of alternative jobs, one should observe that WMFs outperform CFs mainly during the period 1999-2002. The estimates do not seem to support this hypothesis. The status of WMFs significantly reduces the hazard of dissolution under both expansionary and recessionary macroeconomic conditions. Indeed, the

\footnotetext{
${ }^{38}$ This section draws on helpful comments and suggestions provided by an anonymous referee.

${ }^{39}$ The crucial assumption of this model is that the firm faces the same hazard at any age (constant hazard), which allows the inclusion of left-censored firms, i.e. firms that are already active at the beginning of each sub-period (1999 and 2004 respectively). Cox model estimates, also reported in Table 5, provide very similar results.
} 
comparison of point estimates suggests that the magnitude of the effect is slightly larger for the economic boom than for the recession. ${ }^{40}$ The greater survival of WMFs is not just the outcome of defensive strategies implemented by insiders during bad economic times.

\section{$\{\{$ Place Table 5 about here $\}\}$}

A more straightforward explanation is that WMFs survive longer because they are more productive than CFs as some studies have shown (Craig and Pencavel, 1995; Perotin et al, 2012). As reported in Appendix Table A2, firm survival is positively associated with wage growth and WMFs exhibit higher wage growth - a crude proxy of productivity growththan their conventional counterparts, even excluding microenterprises. Unfortunately, the lack of information on output and non-labor inputs in social security records precludes to construct appropriate productivity indicators at the firm level.

Compensation flexibility and employment stability may be other possible mechanisms accounting for the lower risk of dissolution of WMFs. Indeed, there is extensive evidence suggesting that WMFs cope with negative demand shocks differently, exhibiting greater employment stability and wage variability than conventional firms (Craig and Pencavel, 1992; Pencavel et al, 2006, Pencavel, 2012). This empirical regularity has also been proved to hold in the Uruguayan case (Burdín and Dean, 2009). It has also been argued that employment stability may affect firm survival through labor productivity. Long-term employment relations may create better incentives to invest in training and firm-specific human capital. Workers may also be more willing to share productive information with managers as productivity improvements will not jeopardize their jobs (Levine and Parkin, 1994).

Table A2 also reports that WMFs exhibit significantly greater compensation flexibility and employment stability than CFs. In addition, Somewhat surprisingly, information provided in Table 3 shows that compensation flexibility is not a good candidate to explain the greater

\footnotetext{
${ }^{40}$ The effect of WMF on the hazard of exit for the sub-period 1999-2002 is statistically significant only at $10 \%$.
} 
survival of WMFs as surviving firms generally exhibit lower wage variability than dying firms. By contrast, firm survival seems to be positively correlated with employment stability.

To provide additional evidence on the role played by these mechanisms, I estimate the Cox model sequentially adding wage variability and employment variability as control variables. As pointed out, WMFs significantly differ from CFs in terms of these variables. Hence, if some of these factors mediate the relationship between workers' control and firm survival, one would expect that their inclusion will partly absorb the observed effect of WMF. ${ }^{41}$ Results are reported in Table 6. For simplicity, Column (1) of Table 6 reproduces the baseline results excluding microenterprises. ${ }^{42}$ Column (2) presents the estimates of the Cox model including an indicator of wage variability. Consistently with the descriptive analysis presented in Table A2, there is a significantly positive association between wage variability and the hazard of dissolution. The estimated coefficient of WMF remains unchanged compared to the baseline estimates, suggesting that compensation flexibility in itself does not explain the positive association between workers' control and firm survival. Column (3) reports the results of the Cox model in which differences in employment variability between firms are controlled for. There is a positive correlation between employment instability and the hazard of exit. Interestingly, the negative effect of WMFs on the hazard decreases considerably and remains statistically significant only at $10 \%$, suggesting that employment variability is partly picking up the effect of workers' control on survival. Differences in employment variability roughly explain $34 \%$ of the difference in the hazard of dissolution between WMFs and CFs reported in Column (1) of Table $6 .{ }^{43}$

\section{$\{\{$ Place Table 6 about here $\}\}$}

\footnotetext{
${ }^{41}$ This approach is similar to the one adopted by Park et al (2004).

${ }^{42}$ Firms with very short spells (less than 12 months) are excluded by construction as it is not possible to compute the annual change in employment and wages for those firms. This explains the slight variation in the estimates and the number of observations compared to Column (1) of Table 7.

${ }^{43}$ This is computed as $(0.734-0.6) /(1-0.6)=0.34$.
} 
Considering the potential endogeneity of these variables, I perform additional estimates measuring these variables just over the pre-2004 period and studying their effect on the post-2003 likelihood of survival. In this case, the analysis is restricted to pre-2004 cohorts of firms. It is reasonable to assume that the pre-2004 values of these variables are exogenous with respect to the post-2003 firm survival. Results remain qualitatively unchanged. The effect of workers' control on firm survival is lower and no longer significant after controlling for the pre-2004 employment variability (see Appendix Table A7). Therefore, the greater survival of WMFs appears to be partly linked with lower employment variability, implying that employment stability may be a potential mediator between workers' control and firm survival. This result is in line with previous evidence on the effect of employee stock ownership plans (ESOPs) on firm survival (Park et al, 2004)

\section{Conclusions}

Based on a long micro-panel of Uruguayan firms, I conduct a survival analysis comparing WMFs and CFs. In contrast to the theoretical "pessimism" regarding the viability of workers' control in market economies, I find that WMFs exhibit lower hazard rates (longer survival times) than CFs. This finding remains robust to the exclusion of microenterprises, to the exclusion of high firm turnover sectors in which WMFs are less frequently observed and to alternative estimation strategies based on semi-parametric and parametric frailty models. Moreover, the results do not seem to be driven by the differential tax regime applied to WMFs. The hazard of dissolution is $29 \%$ lower for WMFs than for CFs after controlling for differences in the tax burden faced by the two types of firms and excluding microenterprises.

This finding seems to contradict several theoretical predictions that WMF will have performance problems and higher risk of dissolution related, for instance, with poor work incentives, inefficient investment and risk taking decisions and costly collective-choice problems (see, for a review, Dow and Putterman, 2000; Dow, 2003). I do not specifically address whether or not WMFs suffer from some of these problems. Nevertheless, the 
evidence suggests that the disadvantages pointed out in the theoretical literature (if exist) may be counterbalanced by other comparative organizational advantages.

I examine several possible explanations for the results. WMFs outperform CFs under both recessionary and expansionary macroeconomic conditions, suggesting that the greater survivability of WMFs cannot be merely explained by the fact that members exercise their control rights over the dissolution decision when outside job opportunities are scarce. Compensation flexibility does not explain in itself the greater survival of WMFs as firm survival is generally correlated with lower wage variability. The positive effect of workers' control on firm survival seems to be associated with the greater employment stability exhibited by WMFs. Long-term employment relationships may encourage worker-members to make firm-specific investments and facilitate organizational changes which in turn may increase productivity and survival prospects (Levine and Parkin, 1994). Consistently with this argument, survey evidence comparing WMFs and CFs in Uruguay indicates that WMFs employ less supervisors compared with CFs, rely more on mutual monitoring among co-workers and are more likely to introduce organizational innovations such as team work, quality groups, job rotation and consultation mechanisms (Alves et al, 2012).

This study has some caveats that deserve further analysis. First, direct measures of firm productivity were not available. The evidence indicate that greater survivability of WMFs is coupled with higher wage growth compared to CFs. However, wage growth is at best a crude proxy for productivity growth at the firm level. This suggests the importance of conducting further longitudinal studies comparing other performance measures apart from firm survival. ${ }^{44}$ Second, the fact that WMFs survive longer may partially reflect selfselection of both WMFs into industries and workers into organizational forms. It may be the case that WMFs firms are not randomly sorted into industries or, in other words, they enter in industries in which they might face better survival prospects. Workers may be also self-selected into organizational forms according to unobservable characteristics that might also affect firm survival. As Chiappori and Salanié (2003) point out, the combination of unobserved heterogeneity and endogenous matching of agents to contracts is bound to

\footnotetext{
${ }^{44}$ Recent evidence from 2009 cross-section data indicates that Uruguayan WMFs are less capital-intensive and exhibited lower value-added per worker and investment rates than conventional firms (Alves et al, 2012).
} 
create selection biases on the parameters of interest. For instance, cooperatives may be able to attract highly motivated workers (Elster, 1989). Obviously, this selection problem is a potential identification threat common to all studies on WMFs based on observational data (Kremer, 1997: p13). However, recent experiments on team production in which subjects are randomly assigned to "democratic" and conventional workplaces also suggest positive incentive effects associated with worker control (Mellizo et al, 2011).

Notwithstanding these issues, the evidence presented in this paper suggests that the marginal share of WMFs in the population of firms and employment in Uruguay can hardly be explained by the fact that these organizations exhibit a higher hazard of failure than conventional firms. The analysis indicates the importance of focusing the attention on both the obstacles face by workers at the formation stage of a WMF and the growth constraints faced by incumbent WMFs. 


\section{References}

Abramitzky, Ran 2008 The limits of equality: Insights from the Israeli kibbutz Quarterly Journal of Economics 123(3) August 1111-59.

Akerlof George A \& Yellen Janet L 1990. "The Fair Wage-Effort Hypothesis and Unemployment" The Quarterly Journal of Economics MIT Press vol. 105(2) pages 255-83

Alchian Armen A and Harold Demsetz 1972. "Production Information Costs and Economic Organization" American Economic Review American Economic Association vol. 62(5) pages 777-95.

Alves Guillermo Gabriel Burdín Paula Carrasco Andrés Dean and Andrés Rius 2012. "Empleo remuneraciones e inversión en cooperativas de trabajadores y empresas convencionales: nueva evidencia para Uruguay". Unpublished manuscript.

Audretsch David B and Talat Mahmood 1995. "New Firm Survival: New Results Using a Hazard Function" The Review of Economics and Statistics MIT Press vol. 77(1) pages 97-103

Audretsch David B. Enrico Santarelli and Marco Vivarelli 1999. "Start-up size and industrial dynamics: some evidence from Italian manufacturing" International Journal of Industrial Organization Elsevier vol. 17(7) pages 965-983 October.

Baron James N. and Jeffrey Pfeffer 1994. "The Social Psychology of Organizations and Inequality" Social Psychology Quarterly LVII 190-209.

Bartelsman Eric Stefano Scarpetta and Fabiano Schivardi 2005. "Comparative analysis of firm demographics and survival: evidence from micro-level sources in OECD countries" Industrial and Corporate Change Oxford University Press vol. 14(3) 365-391.

Bartlett Will John Cable Saul Estrin Derek C. Jones and Stephen C Smith 1992. Labor-Managed Cooperatives and Private Firms in North Central Italy: An Empirical Comparison. Industrial and Labor Relations Review Vol. 46 No. 1 103-118.

Ben-Ner Avner 1984. "On the stability of the cooperative type of organization" Journal of Comparative Economics Elsevier vol. 8(3) pages 247-260 September.

Ben-Ner Avner. 1988a. The life cycle of worker-owned firms in market economies. Journal of Economic Behavior and Organization Vol. 10 No. 3 287-313.

Ben-Ner Avner 1988b. "Comparative empirical observations on worker-owned and capitalist firms" International Journal of Industrial Organization Elsevier vol. 6(1) pages 7-31 March.

Bonin John P. Derek C. Jones and Louis Putterman 1993. "Theoretical and empirical studies of producer cooperatives: will ever the twain meet". Journal of Economic Literature Vol. 31 No. 3 1290-1320. 
Bowles Samuel and Herbert Gintis 1994. "Credit market imperfections and the incidence of workerowned firms" Metroeconomica 45 pp. 209-223.

Bryson Alex 2004. "Unions and Workplace Closure in Britain 1990-1998" British Journal of Industrial Relations 42:283-302.

Bucheli Marisa and Andrés Vigna 2006. "Presentación de la política de exoneraciones de aportes a la seguridad social en Uruguay". Documento No. 12/06. DECON-FCS-UdelaR.

Burdín Gabriel and Andrés Dean 2009. "New evidence on wages and employment in worker cooperatives compared with capitalist firms”. Journal of Comparative Economics. Vol 34. Issue 4: 517-533.

Burdín Gabriel and Andrés Dean 2010. "El comportamiento demográfico de las cooperativas de trabajadores: observaciones empíricas y nuevas preguntas para el caso uruguayo" in Gestión obrera: del fragmento a la acción colectiva. Ed. Nordan Comunidad. SCEAM-UdelaR.

Burdín Gabriel and Andrés Dean 2012. "Revisiting the objectives of worker-managed firms: an empirical assessment”. Economic Systems vol 36 Issue 1 March 2012 Pages 158-171.

Caves Richard E. 1998. "Industrial Organization and New Findings on the Turnover and Mobility of Firms" Journal of Economic Literature 36 1947-82.

Cleves Mario William W. Gould Roberto G. Gutierrez and Yulia Marchenko 2008. "An Introduction to Survival Analysis Using Stata". 2nd Edition. Stata Press. 372; paperback

Chiappori Pierre Andre and Bernard Salanie 2003. "Testing Contract Theory: A Survey of Some Recent Work" in Advances in Economics and Econometrics vol 1 M. Dewatripont L. Hansen and S. Turnovsky eds Cambridge University Press.

Cox David R. 1972. "Regression Models and Life Tables" Journal of the Royal Statistical Society Series B 34:187-220.

Craig Ben and John Pencavel 1992. "The behavior of workers cooperatives: the plywood companies of the pacific northwest”. American Economic Review Vol. 82 No. 5 1083-1105.

Craig Ben and John Pencavel 1995. "Participation and productivity: a comparison of worker cooperatives and conventional firms of the Pacific Northwest”. Brookings Papers: Microeconomics pp. 121-174.

DiNardo John and David. S. Lee 2004. "Economic Impacts of New Unionization on Private Sector Employers: 1984-2001” Quarterly Journal of Economics 119: 1328-1441

Doucouliagos Chris. 1995. "Worker participation and productivity in labor-managed firms and participatory capitalist firms: a meta-analysis”. Industrial and Labor Relations Review 49 5877. 
Dow Gregory 1986. Control rights competitive markets and the labor management debate. Journal of Comparative Economics Vol.10 No. $148-61$.

Dow Gregory 2001. Allocating control over firms: Stock markets versus membership markets. Review of Industrial Organization Vol. 18 -No. 2 201-218.

Dow Gregory 2003. "Governing the firm: Workers control in theory and practice”. Cambridge University Press New York.

Dow Gregory and Louis Putterman 2000. "Why capital suppliers (usually) hire workers: What we know and what we need to know". Journal of Economic Behavior and Organization Vol. 43 No. 3 319-336.

Elster Jon 1989. "From here to there; or If cooperative ownership is so desirable why are there so few Cooperatives?” Social Philosophy and Policy Spring 19896 (2):93-111.

Esteve-Perez Silviano Amparo Llopis and Juan Llopis 2004. "The Determinants of Survival of Spanish Manufacturing Firms" Review of Industrial Organization Springer vol. 25(3) pages 251-27308

Estrin Saul and Milica Uvalic 2008. From Illyria towards capitalism: Did labour-management theory teach us anything about Yugoslavia and transition in its successor states? Comparative Economic Studies 50 663-696.

Fakhfakh Fathi Virginie Pérotin and Mónica Gago 2012. "Productivity Capital and Labor in LaborManaged and Conventional Firms" Industrial and Labor Relations Review (forthcoming).

Freeman Richard B. and Morris M. Kleiner 1999. "Do unions make enterprises insolvent?" Industrial and Labor Relations Review ILR Review Cornell University ILR School vol. 52(4) pages 510-527.

Freeman John Glenn R. Carroll and Michael T. Hannan 1983. "The liability of newness: Age dependence in organizational death rates". American Sociological Review 48: 692-710.

Furubotn Erik. 1976; "The long run analysis of the labor managed firms: an alternative interpretation". American Economic Review. Vol 76 №1.

Gimeno Javier Timothy B. Folta Arnold C. Cooper and Carolyn Y. Woo 1997. "Survival of the fittest? Entrepreneurial human capital and the persistence of underperforming firms" Administrative Science Quarterly 42750-783.

Geroski Paul 1995. "What do we know about entry? International Journal of Industrial Organization 13 421-40.

Geroski Paul Jose Mata and Pedro Portugal 2010. "Founding Conditions and the Survival of New Firms" Strategic Management Journal 31 510—529. 
Gonzalez Gustavo and Montero Marcelo 2008. “Caracterización de la rentabilidad de las empresas a través de las declaraciones del IRIC y un ejercicio de simulación sobre algunos cambios del Nuevo Sistema Tributario". Asesoría Económica - DGI.

Gui Benedetto 1984. "Basque versus lllyrian Labor-Managed Firms: The Problem of Property Rights”. Journal of Comparative Economics. 8 168-181.

Gui Benedetto 1987. "Internal pay schedules and labour mobility: the problem of firm survival". Economic notes pages 89-100.

Hansmann Henry. 1996. "The ownership of enterprise”. The Belknap Press of Harvard University Press. Cambridge MA.

Jenkins Stephen 2005. "Survival analysis”. Institute for Social and Economic Research. University of ESSEX UK. http://www.iser.essex.ac.uk/resources/survival-analysis-with-stata-moduleec968.

Jones Derek 2007. "The Productive Efficiency of Italian Producer Cooperatives: Evidence from Conventional and Cooperative Firms" Advances in the Economic Analysis of Participatory and Labour Managed Firms vol 102007 pp.3-28.

Jovanovic Boyan 1982. "Selection and Evolution of Industry" Econometrica 50 649-670.

Kremer Michael 1997. "Why are worker cooperatives so rare". NBER Working Paper 6118.

Kruse Douglas L. Richard B. Freeman and Joseph R. Blasi 2010. "Shared Capitalism at Work: Employee Ownership Profit and Gain Sharing and Broad-based Stock Options" NBER Books National Bureau of Economic Research Inc number krus08-1 September.

Levine David 1991. "Cohesiveness Productivity and Wage Dispersion" Journal of Economic Behavior and Organization Elsevier vol. 15(2) pages 237-255 March.

Levine David and Richard Parkin 1994. "Work organization employment security and macroeconomic stability". Journal of Economic Behavior and Organization. 24 251-271.

Manjon Miguel and Josep-Maria Arauzo-Carod 2008. "Firm survival: methods and evidence" Empirica Springer vol. 35(1) pages 1-24 March.

Mata Jose and Pedro Portugal 1994. "Life Duration of New Firms" Journal of Industrial Economics Wiley Blackwell vol. 42(3) pages 227-45

Mata Jose and Pedro Portugal 2002. "The Survival of New Domestic and Foreign Owned Firms" Strategic Management Journal 23 323-343

Mellizo Philip Jeffrey Carpenter and Peter Hans Matthews 2011. "Workplace Democracy in the Lab” IZA Discussion Paper No. 5460.

Moene Karl Ove 1989. "Strong Unions or Worker Control" in Elster Jon and Karl Ove Moene (eds) Alternatives to Captalism. Cambridge University Press. 
Park Rhokeun Douglas Kruse and James Sesil 2004. "Does employee ownership enhance firm survival?” Advances in the Economic Analysis of Participatory and Labor-Managed Firms 8 3-34.

Pencavel John 2012. "Worker cooperatives and democratic governance" in Anna Gandori (ed.) The Handbook of Economic Organization. Integrating Economic and Organization Theory Edward Elgar. Routledge (in press).

Pencavel John Luigi Pistaferri and Fabiano Schivardi 2006. "Wages employment and capital in capitalist and worker-owned firms”. Industrial and Labor Relations Review vol 60 No. $123-$ 44.

Pérotin Virginie 1987. "Conditions of survival and closure of French worker cooperatives: Some preliminary findings". Advances in the Economic Analysis of Participatory and LaborManaged Firms 2 201-224.

Pérotin Virginie 2004. "Early cooperative survival: The liability of adolescence". Advances in the Economic Analysis of Participatory and Labor-Managed Firms 8 67-86.

Pérotin Virginie 2006. "Entry exit and the business cycle. Are cooperatives different?. Journal of Comparative Economics. № 34 295-316.

Pfeiffer Friedhelm and Reize Frank 2000. "Business Start-ups by the Unemployed - An Econometric Analysis Based on Firm Data” Labour Economics 7 629-63.

Samuelson Paul A. 1957. "Wages and interest: a modern dissection of Marxian economic models". The American Economic Review Vol. 47 No. 6 (Dec. 1957) pp. 884-912

Santarelli Enrico and Marco Vivarelli 2007. "Entrepreneurship and the process of firms' entry survival and growth" Industrial and Corporate Change Oxford University Press vol. 16(3) pages 455-488 June

Staber Udo. 1989. "Age-Dependence and Historical Effects on the Failure Rates of Worker Cooperatives: An Event-History Analysis" Economic and Industrial Democracy 10 pp. 5980.

Stinchcombe Arthur 1965. "Social Structure and Organizations" in: March J.G. (ed.) Handbook of Organizations. Chicago: Rand McNally \& Company 142-193.

Vivarelli Marco and David Audretsch 1998 "The Link between the Entry Decision and Post-entry Performance: Evidence from Italy" Industrial and Corporate Change 7 485-500

Ward Benjamin 1958. "The firm in Illyria: market syndicalism”. American Economic Review. Vol. 48 No. 4 566-589.

Wooldridge Jeffrey M. 2001. "Econometric Analysis of Cross Section and Panel Data" MIT Press Books The MIT Press edition 1 volume 1. 


\section{Appendix}

Table A1. Descriptive survival statistics

\begin{tabular}{lccccc}
\hline \hline & \multicolumn{5}{c}{ per-firm } \\
\hline \hline & Total & Mean & Min & Median & Max \\
\cline { 2 - 6 } All firms & & & & & \\
No. of firms & 29125 & & & & \\
No. of records & 1258606 & & & & \\
(Final) Exit time & & 45.63 & 1 & 35 & 150 \\
Firms with gap & 4546 & & & & \\
No. of gaps & 6497 & & & & \\
Time on gap if gap & 70974 & 10.92 & 1 & 5 & 138 \\
Time at risk & 1258606 & 43.21 & 1 & 32 & 150 \\
Failures & 15308 & 0.53 & 0 & 1 & 1
\end{tabular}

$\underline{C F s}$

No. of firms 28821

No. of records 1244542

(Final) Exit time

Firms with gap

No. of gaps

Time on gap if gap

Time at risk

Failures

$\underline{\text { All PCs }}$

No. of firms

No. of records

(Final) Exit time

Firms with gap

No. of gaps

Time on gap if gap

Time at risk

Failures

WMFs

No. of firms

No. of records

(Final) Exit time

Firms with gap

No. of gaps

Time on gap if gap

Time at risk

Failures

4520

6466

70668

1244542

15177

304

14064

26

31

306

14064

131

223

10179

14

17

90

$\begin{array}{llll}45.63 & 1 & 35 & 150\end{array}$

10.93

$\begin{array}{llll}43.18 & 1 & 32 & 150\end{array}$

$\begin{array}{llll}0.53 & 0 & 1 & 1\end{array}$

$\begin{array}{llll}47.27 & 1 & 37 & 147\end{array}$

9.87

46.26

0.43

1
1

1

$6 \quad 51$

$\begin{array}{llll}46.18 & 1 & 38 & 145\end{array}$

$\begin{array}{lllll}118 & 6.94 & 1 & 6 & 26\end{array}$

$\begin{array}{lllll}10179 & 45.65 & 1 & 38 & 145\end{array}$

$\begin{array}{llll}0.40 & 0 & 0 & 1\end{array}$

Notes: the total number of records divided by the number of firms gives the mean number of monthly records (mean time at risk) per firm (43.18 months). The difference between the final exit time and the number of records (or time at risk) is due to firms with gap. Time on gap if gap refers to the length of the gap. The median gap lasts 5 months. The total Time on gap if gap computed as the mean Time on gap if gap times the number of gaps (there are firms' spells with multiple gaps). Failure is a dummy variable which takes value 1 (at the exit date) if the firm exits during the period and 0 otherwise. Source: Authors' calculation using data from the Banco de Previsión Social. 
Table 1. Descriptive statistics of firm-level variables

\begin{tabular}{|c|c|c|c|c|c|c|c|c|c|c|}
\hline & \multicolumn{2}{|c|}{ 1997-1999 } & \multicolumn{2}{|c|}{$2000-2002$} & \multicolumn{2}{|c|}{$2003-2005$} & \multicolumn{2}{|c|}{$2006-2009$} & \multicolumn{2}{|c|}{ Total } \\
\hline & 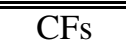 & "WMFs & 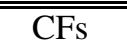 & "WMFs & CFs & "WMFs & $\overline{\mathrm{CFs}}$ & "WMFs & 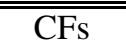 & "WMFs \\
\hline Firm start-up size (in logs) & $\begin{array}{c}0.72 \\
(0.90)\end{array}$ & $\begin{array}{c}2.42 \\
(0.74)\end{array}$ & $\begin{array}{c}0.81 \\
(0.95)\end{array}$ & $\begin{array}{c}2.24 \\
(1.19)\end{array}$ & $\begin{array}{c}0.78 \\
(0.91)\end{array}$ & $\begin{array}{c}2.13 \\
(0.90)\end{array}$ & $\begin{array}{c}0.76 \\
(0.93)\end{array}$ & $\begin{array}{c}2.02 \\
(0.84)\end{array}$ & $\begin{array}{c}0.76 \\
(0.92)\end{array}$ & $\begin{array}{c}2.22 \\
(0.95)\end{array}$ \\
\hline Start-up average wage (in $\operatorname{logs}$ ) & $\begin{array}{c}8.34 \\
(0.92)\end{array}$ & $\begin{array}{c}7.44 \\
(1.35)\end{array}$ & $\begin{array}{c}8.24 \\
(0.96)\end{array}$ & $\begin{array}{c}7.62 \\
(1.31)\end{array}$ & $\begin{array}{c}7.96 \\
(0.93)\end{array}$ & $\begin{array}{c}7.46 \\
(1.16)\end{array}$ & $\begin{array}{c}8.29 \\
(0.90)\end{array}$ & $\begin{array}{c}7.55 \\
(1.39)\end{array}$ & $\begin{array}{c}8.21 \\
(0.94)\end{array}$ & $\begin{array}{c}7.51 \\
(1.29)\end{array}$ \\
\hline Effective tax burden & $\begin{array}{c}0.086 \\
(0.049)\end{array}$ & $\begin{array}{c}0.023 \\
(0.042)\end{array}$ & $\begin{array}{c}0.081 \\
(0.053)\end{array}$ & $\begin{array}{c}0.014 \\
(0.031)\end{array}$ & $\begin{array}{c}0.075 \\
(0.049)\end{array}$ & $\begin{array}{c}0.006 \\
(0.014)\end{array}$ & $\begin{array}{c}0.075 \\
(0.028)\end{array}$ & $\begin{array}{c}0.005 \\
(0.016)\end{array}$ & $\begin{array}{c}0.081 \\
(0.049)\end{array}$ & $\begin{array}{c}0.013 \\
(0.030)\end{array}$ \\
\hline Sectoral composition (\%) & & & & & & & & & & \\
\hline Manufacturing & 27.85 & 13.52 & 25.43 & 27.19 & 27.44 & 16.70 & 23.98 & 25.05 & 26.69 & 19.76 \\
\hline Transport & 13.52 & 9.06 & 10.48 & 11.04 & 13.80 & 8.00 & 13.67 & 5.57 & 12.82 & 8.78 \\
\hline Services & 25.72 & 54.07 & 28.94 & 50.88 & 26.72 & 44.16 & 33.88 & 45.57 & 27.71 & 48.90 \\
\hline Other sectors & 32.91 & 23.35 & 35.14 & 10.89 & 32.04 & 31.15 & 28.47 & 23.81 & 32.78 & 22.56 \\
\hline Size composition (\%) & & & & & & & & & & \\
\hline Micro firms & 85.35 & 3.5 & 82.53 & 24.31 & 84.2 & 25.09 & 84.64 & 25.64 & 84.26 & 18.96 \\
\hline Small firms & 12.1 & 80.5 & 14.56 & 50.69 & 13.23 & 59.47 & 12.2 & 58.1 & 13.03 & 62.77 \\
\hline Medium firms & 2.5 & 11.68 & 2.74 & 21.64 & 2.43 & 15.44 & 2.98 & 16.26 & 2.6 & 16.17 \\
\hline Large firms & 0.05 & 4.32 & 0.17 & 3.36 & 0.15 & 0 & 0.19 & 0 & 0.12 & 2.1 \\
\hline
\end{tabular}

Notes: Wages are defined as the firm wage bill divided by total employment and measured as pesos uruguayos deflacted by the official Consumer Price Index (IPC). Start-up size defined as the $\log$ of employment at the time of entry. Start-up wage defined as the log of firm average wage measured at the time of entry. Tax burden is the effective employer payroll tax rate. Firms are classified in four categories according to their start-up size: micro (less than 6 workers), small (between 6 and 19), medium (between 20 and 99) and large (100 or more workers). The category "Other Sectors" includes Construction, Electricity and Retail Trade. Standard deviations in parentheses. Source: Authors' calculation using data from the Banco de Previsión Social. 
Figure A1. Birth rates of WMFs and CFs. Period 1998-2009

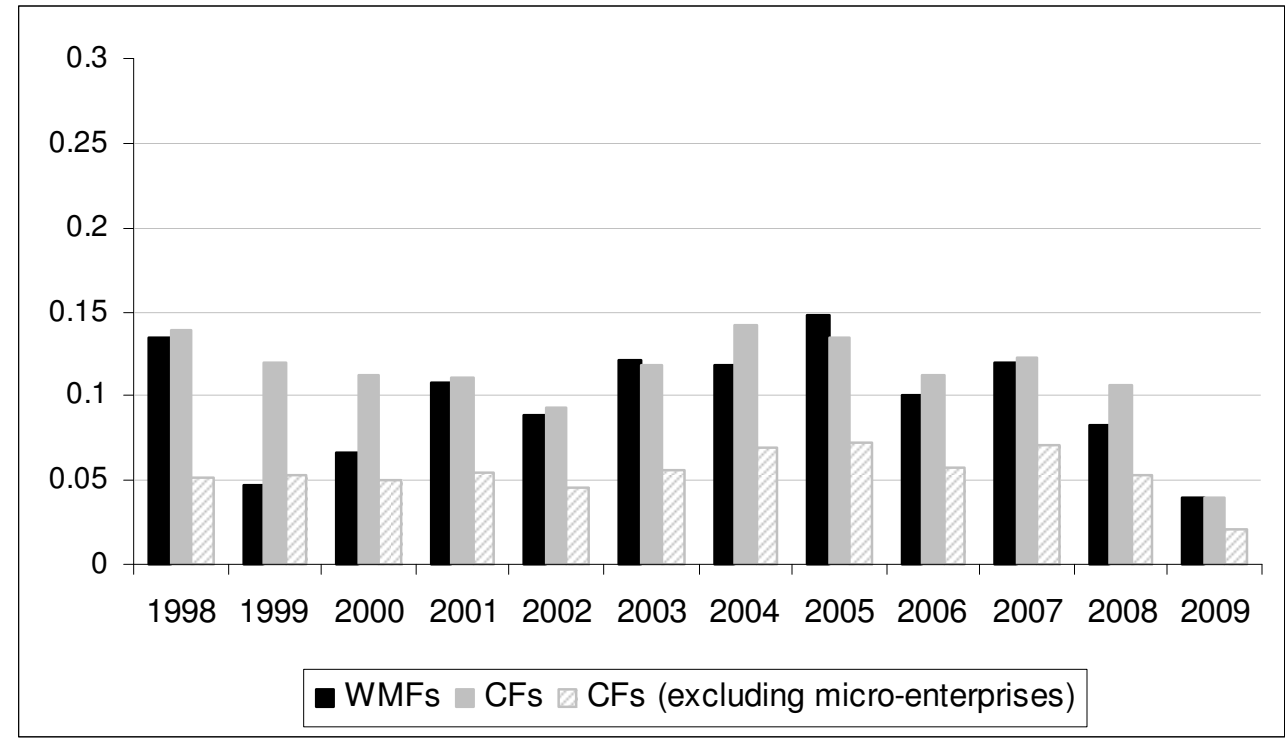

Notes: Annual birth rates calculated as the number of entering firms divided by the total number of firms in the previous year. In 2009, only the period January-July is considered. Source: Authors' calculation using data from the Banco de Previsión Social.

Figure A2. Exit rates of WMFs and CFs. Period 1998-2009

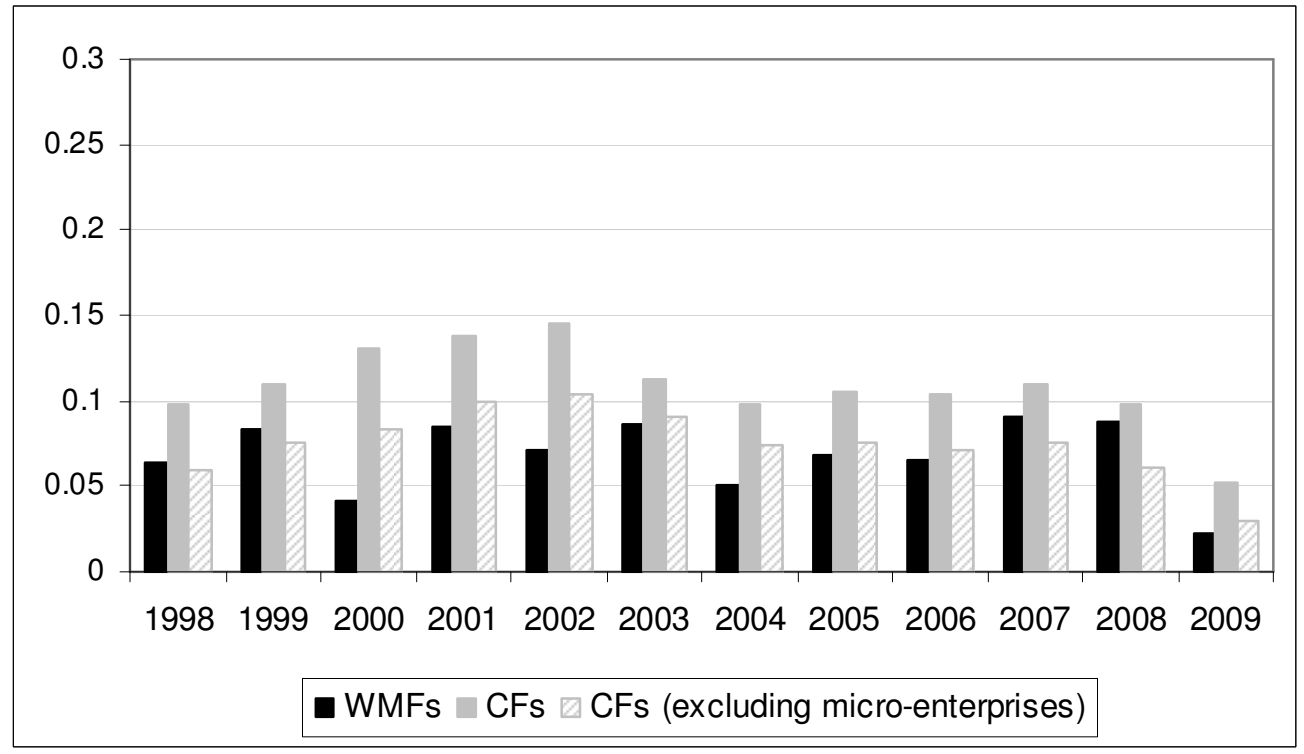

Note: Annual exit rates calculated as the number of exiting firms divided by the total number of firms in the previous year. In 2009, only the period January-July is considered. Source: Authors' calculation using data from the Banco de Previsión Social. 
Table A2. Employment and wage dynamic

\begin{tabular}{ccccc}
\hline \hline & Total & Dying firms & Surviving firms & t-stat (i) \\
\hline \hline$\underline{\text { All firms }}$ Employment growth & & & & \\
WMFs & 0.022 & -0.064 & 0.050 & $(8.47)^{* * *}$ \\
CFs & 0.072 & -0.008 & 0.107 & $(94.80)^{* * *}$ \\
t-stat (ii) & $(10.31)^{* * *}$ & $(4.46)^{* * *}$ & $(11.87)^{* * *}$ &
\end{tabular}

Wage growth

$\begin{array}{ccccc}\text { WMFs } & 0.071 & -0.006 & 0.093 & (4.67)^{* * *} \\ \text { CFs } & 0.048 & -0.001 & 0.073 & (77.21)^{* * *} \\ \text { t-stat (ii) } & 3.28 * * * & 0.21 & 2.94 * * * & \end{array}$

Employment variability

$\begin{array}{ccccc}\text { WMFs } & 0.267 & 0.329 & 0.244 & 11.17 * * * \\ \text { CFs } & 0.370 & 0.395 & 0.358 & 64.82 * * * \\ \text { t-stat (ii) } & (37.26)^{* * *} & (9.27)^{* * *} & (41.54)^{* * *} & \end{array}$

Wage variability

$\begin{array}{ccccc}\text { WMFs } & 0.460 & 0.605 & 0.409 & 22.46 * * * \\ \text { CFs } & 0.353 & 0.392 & 0.333 & 120.44 * * * \\ \text { t-stat (ii) } & 30.79^{* * *} & 26.61^{* * *} & 21.22^{* * *} & \end{array}$

Excluding microenterprises

Employment growth

$\begin{array}{ccccc}\text { WMFs } & -0.007 & -0.010 & 0.021 & (8.31)^{* * *} \\ \text { CFs } & -.0176 & -0.166 & 0.047 & (58.40)^{* * *} \\ \text { t-stat (ii) } & 2.19^{* *} & 4.66^{* * *} & (5.34)^{* * *} & \end{array}$

Wage growth

$\begin{array}{ccccc}\text { WMFs } & 0.054 & -0.059 & 0.084 & (6.12)^{* * *} \\ \text { CFs } & 0.031 & -0.039 & 0.059 & (31.97)^{* * *} \\ \text { t-stat (ii) } & 3.09 * * * & (0.89) & 3.33^{* * *} & \end{array}$

Employment variability

$\begin{array}{ccccc}\text { WMFs } & 0.232 & 0.296 & 0.211 & 9.89^{* * *} \\ \text { CFs } & 0.377 & 0.510 & 0.311 & 112.87^{* * *}\end{array}$

Wage variability

\begin{tabular}{ccccc} 
WMFs & 0.434 & 0.576 & 0.387 & $18.48 * * *$ \\
CFs & 0.352 & 0.452 & 0.303 & $93.10^{* * *}$ \\
t-stat (ii) & $(21.33) * * *$ & $12.90 * * *$ & $22.21 * * *$ & \\
\hline
\end{tabular}

Notes: employment and wage growth rates defined as the annual change in employment and wages respectively (in $\log$ form) such that, $\Delta \ln E_{i t}=\ln E_{i t}-\ln E_{i t-k}$ and $\Delta \ln w_{i t}=\ln w_{i t}-\ln w_{i t-k}$. Employment and wage variability measured as the standard deviation of annual changes in the log of employment and wages respectively. (i) Test for differences between dying and surviving firms. (ii) Test for difference between WMFs and CFs. Source: Authors' calculation using data from the Banco de Previsión Social. 
Figure 1. Survivor and hazard functions. Non parametric estimates.

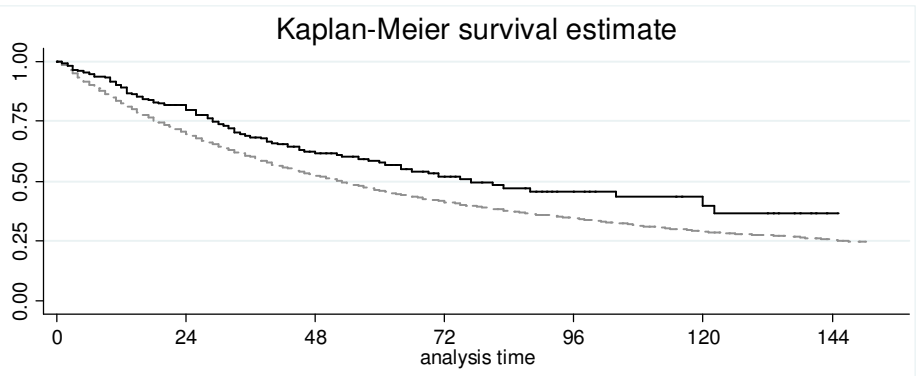

Smoothed hazard estimate

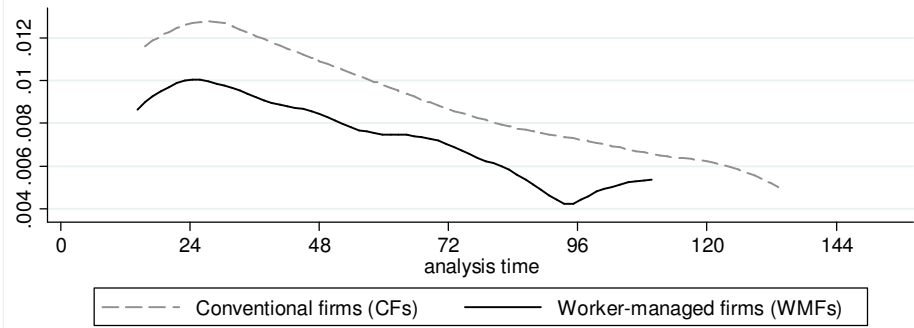

Notes: the Kaplan-Meier survivor function is defined as $\hat{S}\left(t_{j}\right)=\prod_{j \mid t_{j}<t}\left(1-\frac{d_{j}}{n_{j}}\right)$, where $d_{j}$ is the number of failures occurring at time $t_{j}$ and $n_{j}$ is the number at risk at $t_{j}$ before the occurrence of the failures. The hazard function is calculated as a weighted kernel-density using the estimated hazard contributions, $\Delta \hat{H}\left(t_{j}\right)=\hat{H}\left(t_{j}\right)-\hat{H}\left(t_{j-1}\right)$, where $t_{j}$ is the current failure time and $\hat{H}\left(t_{j}\right)$ is the estimated cumulative hazard. The Nelson-Aalen estimator of $\hat{H}\left(t_{j}\right)$ is defined as $\hat{H}\left(t_{j}\right)=\sum_{j \mid t_{j} \leq t}\left(\frac{d_{j}}{n_{j}}\right)$, i.e. the sum of the expected number of failures at each observed time. See Jenkins (2005) and Cleves et al (2008) for further details on nonparametric survival analysis. 
Figure 2. Survivor function of WMFs and CFs by firm cohorts and sectors.

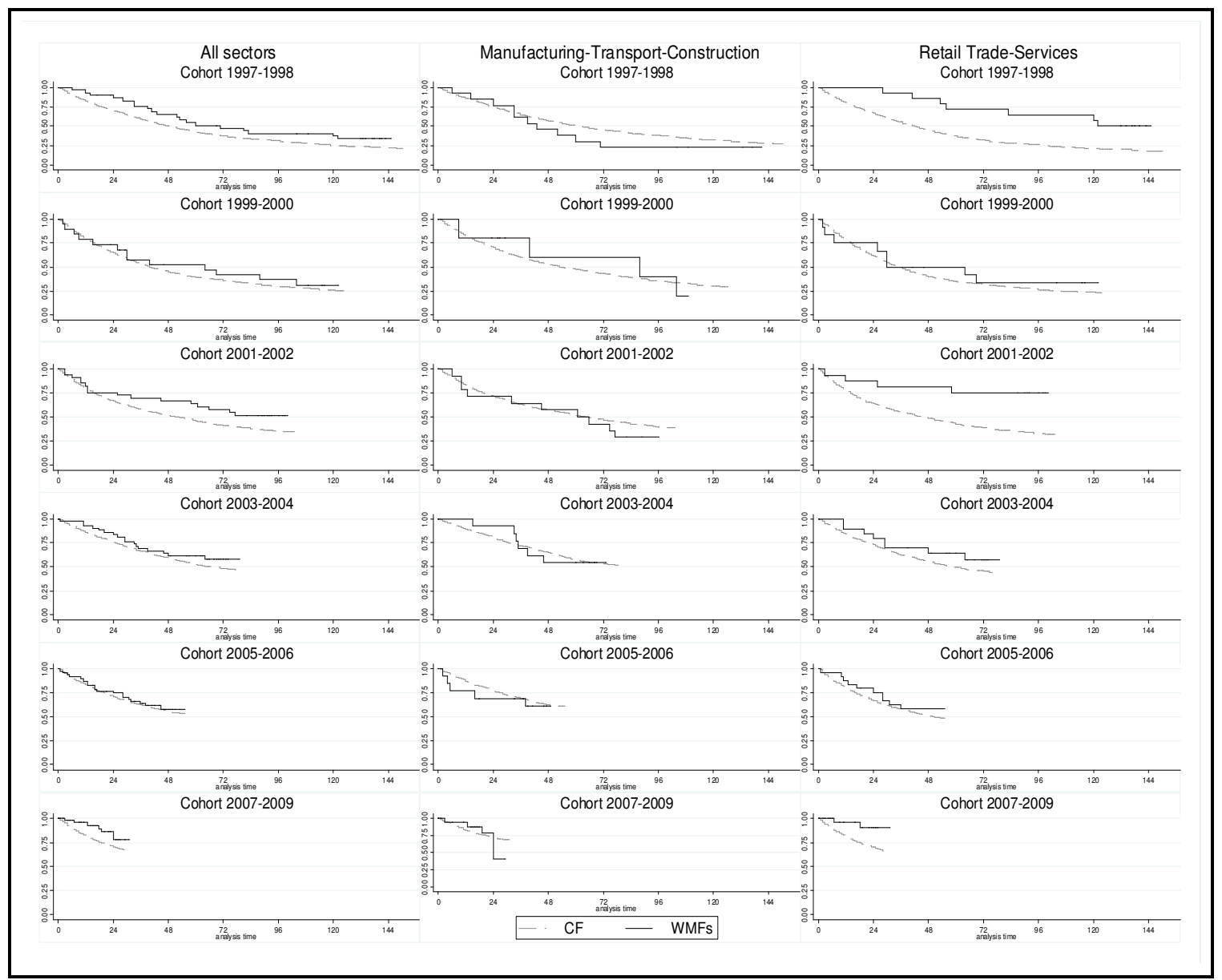

Notes: plots of the Kaplan-Meier survivor function, defined as $\hat{S}\left(t_{j}\right)=\prod_{j \mid t_{j}<t}\left(1-\frac{d_{j}}{n_{j}}\right)$, where $d_{j}$ is the number of failures occurring at time $t_{j}$ and $n_{j}$ is the number at risk at $t_{j}$ before the occurrence of the failures. The right-hand side panels plot the survivor function estimated pooling all sectors. The left hand side panels plot the survivor function considering retail trade and services firms. Panels displayed to the center consider Manufacturing, construction and transport firms. 
Figure A3. Graphical check of the Proportional Hazard assumption

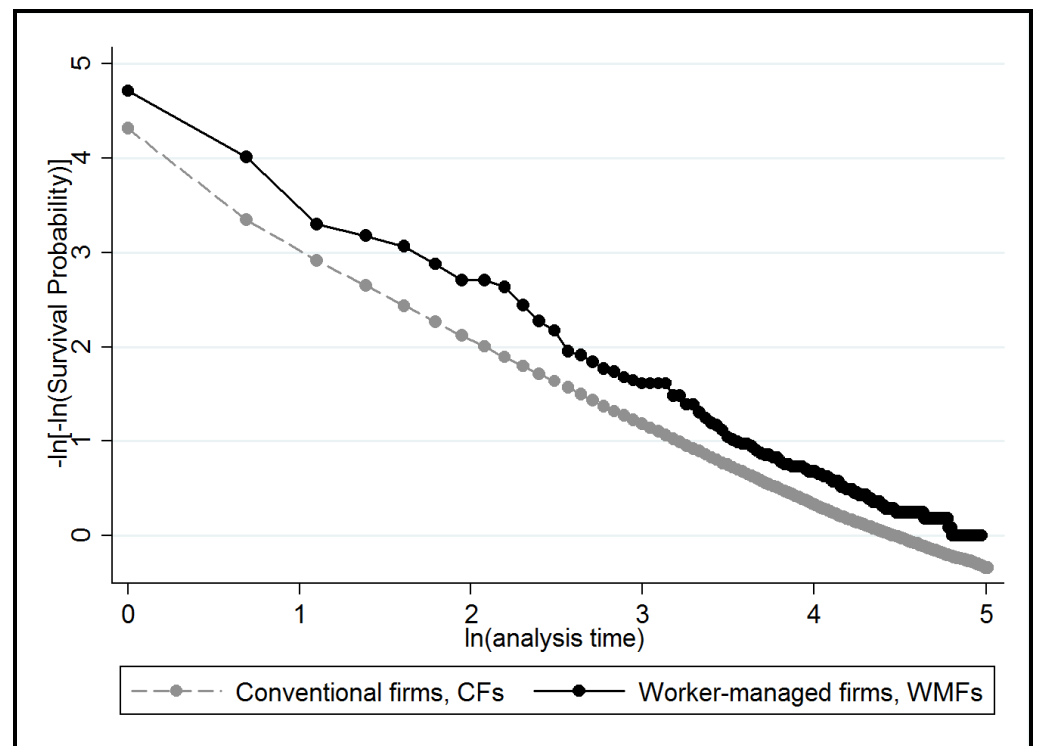

Notes: This figure depicts the plot of the transformation $-\ln [-\ln \{\hat{S}(t)\}]$ versus $\ln (t)$ for CFs and WMFs, where $\hat{S}(t)$ is the Kaplan- Meier estimate of the survivor function. Under the proportional hazard assumption, the curves should be parallel.

Table 2. Cox Model estimates

\begin{tabular}{lccc}
\hline \hline & $(1)$ & $(2)$ & $(3)$ \\
\hline \hline & & & \\
Coop & $-0.326^{* * *}$ & $-0.298^{* * *}$ & $-0.293^{* * *}$ \\
& $(0.107)$ & $(0.109)$ & $(0.110)$ \\
Firm start-up size & $-0.058^{* * *}$ & $-0.076^{* * *}$ & $-0.071^{* * *}$ \\
& $(0.01)$ & $(0.01)$ & $(0.01)$ \\
Firm start-up wage & $-0.156^{* * *}$ & $-0.148^{* * *}$ & $-0.170^{* * *}$ \\
& $(0.009)$ & $(0.009)$ & $(0.009)$ \\
Hazard ratio & $\mathbf{0 . 7 2 2}$ & $\mathbf{0 . 7 4 2}$ & $\mathbf{0 . 7 4 6}$ \\
Industry fixed effects & No & Yes & Yes \\
Cohort fixed effects & No & No & Yes \\
Observations & 1245207 & 1245207 & 1245207 \\
\hline \hline
\end{tabular}

Notes: Start-up size defined as the log of employment at the time of entry. Start-up wage defined as the log of firm average wage measured at the time of entry. In Column (2)-(3), estimates include 4 industry dummies (distinguishing Manufacturing, Transport, Services and Other Sectors). In column (3), estimates include 13 cohort dummies. The hazard ratio is obtained computing $\exp \left(\beta^{\text {coop }}\right)$. Robust standard errors in parentheses. Standard errors are clustered at the firm level. * Statistically significant at .10 level; ** at the .05 level; *** at the .01 level 
Table A3. Test of proportional hazard assumption

\begin{tabular}{lrr}
\hline \hline & Chi-square & p-value \\
\hline \hline Coop & 0.11 & 0.7420 \\
Firm start-up size & 5.49 & 0.0192 \\
Firm start-up wage & 31.8 & 0.0000 \\
Sectoral dummies & & \\
(Manufacturing) & & \\
Transport & 0.81 & 0.3695 \\
Services & 5.8 & 0.0161 \\
Other sectors & 50.02 & 0.0000 \\
Cohort dummies & & \\
(1997) & & \\
1998 & 30.42 & 0.0000 \\
1999 & 39.76 & 0.0000 \\
2000 & 52.58 & 0.0000 \\
2001 & 62.85 & 0.0000 \\
2002 & 26.93 & 0.0000 \\
2003 & 7.13 & 0.0076 \\
2004 & 17.34 & 0.0000 \\
2005 & 25.17 & 0.0000 \\
2006 & 27.43 & 0.0000 \\
2007 & 19.36 & 0.0000 \\
2008 & 14.42 & 0.0001 \\
2009 & 2.77 & 0.0962 \\
Global test & 218.31 & 0.0000 \\
\hline \hline
\end{tabular}

Notes: Test based on Schoenfeld residuals. Rejection of the null hypothesis indicate a deviation from the proportional hazard assumption.

Figure A4. Hazard function of WMFs and CFs

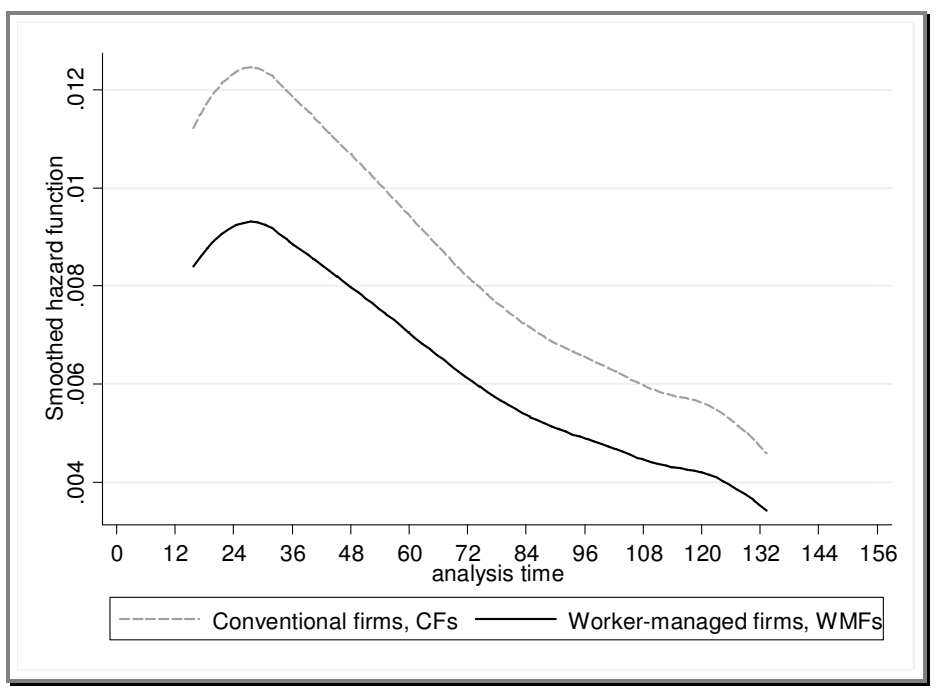

Notes: Cox model post estimation 
Table 3. Cox Model estimates (within industries)

\begin{tabular}{lcccc}
\hline \hline & $(1)$ & $(2)$ & $(3)$ & $(4)$ \\
\hline \hline & $\begin{array}{c}\text { All firms } \\
\text { (excluding Construction } \\
\text { and Retail Trade) }\end{array}$ & Manufacturing & Transport & Services \\
\cline { 2 - 5 } Coop & & & & \\
Firm start-up size & $-0.272^{* *}$ & 0.173 & 0.014 & $-0.619^{* * *}$ \\
& $(0.118)$ & $(0.190)$ & $(0.288)$ & $(0.189)$ \\
Firm start-up wage & $-0.082^{* * *}$ & $-0.079^{* * *}$ & 0.009 & $-0.094^{* * *}$ \\
& $(0.012)$ & $(0.020)$ & $(0.040)$ & $(0.017)$ \\
Industry fixed effects & $-0.165^{* * *}$ & $-0.164^{* * *}$ & $-0.238^{* * *}$ & $-0.148^{* * *}$ \\
Cohort fixed effects & $(0.011)$ & $(0.020)$ & $(0.030)$ & $(0.016)$ \\
Observations & Yes &.-- &.-- &.-- \\
\hline \hline
\end{tabular}

Notes: Start-up size defined as the log of employment at the time of entry. Start-up wage defined as the log of firm average wage measured at the time of entry. In column (1), estimates include 4 industry dummies (distinguishing Manufacturing, Transport, Services and Other Sectors). All estimates include 13 cohort dummies. Robust standard errors in parentheses. Standard errors are clustered at the firm level. * Statistically significant at .10 level; ** at the .05 level; $* * *$ at the .01 level 
Table 4. Robustness checks

\begin{tabular}{|c|c|c|c|c|c|c|}
\hline & \multicolumn{3}{|c|}{ Semi-parametric models } & \multicolumn{3}{|c|}{ Parametric models } \\
\hline & \multicolumn{4}{|c|}{ Proportional Hazard } & \multicolumn{2}{|c|}{ Accelerated Failure Time } \\
\hline & & Cox model & & Weibull & Log-logistic & 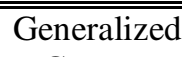 \\
\hline & (1) & (2) & (3) & (4) & $(5)$ & (6) \\
\hline Coop & $\begin{array}{c}-0.502 * * * \\
(0.138)\end{array}$ & $\begin{array}{c}-0.476^{* * *} \\
(0.151)\end{array}$ & $\begin{array}{c}-0.338 * * \\
(0.168)\end{array}$ & $\begin{array}{c}-0.705^{* * * *} \\
(0.209)\end{array}$ & $\begin{array}{c}0.533 * * * \\
(0.160)\end{array}$ & $\begin{array}{c}0.545 * * * \\
(0.156)\end{array}$ \\
\hline Firm start-up size & $\begin{array}{l}-0.009 \\
(0.033)\end{array}$ & $\begin{array}{l}-0.010 \\
(0.033)\end{array}$ & $\begin{array}{l}-0.039 \\
(0.038)\end{array}$ & $\begin{array}{l}-0.009 \\
(0.049)\end{array}$ & $\begin{array}{c}0.005 \\
(0.037)\end{array}$ & $\begin{array}{c}0.023 \\
(0.038)\end{array}$ \\
\hline Firm start-up wage & $\begin{array}{c}-0.243 * * * \\
(0.025)\end{array}$ & $\begin{array}{c}-0.245^{* * * *} \\
(0.025)\end{array}$ & $\begin{array}{c}-0.239 * * * \\
(0.026)\end{array}$ & $\begin{array}{c}-0.430 * * * \\
(0.042)\end{array}$ & $\begin{array}{c}0.327 * * * \\
(0.030)\end{array}$ & $\begin{array}{c}0.318 * * * \\
(0.03)\end{array}$ \\
\hline Tax burden & & & $\begin{array}{c}0.032 * * * \\
(0.008)\end{array}$ & & & \\
\hline Hazard ratio & 0.605 & 0.621 & 0.713 & 0.494 &.-- & $-\because$ \\
\hline$\kappa$ & & & & & & $\begin{array}{c}0.029 \\
(0.071)\end{array}$ \\
\hline$\sigma$ & & & & & & $\begin{array}{c}1.481 \\
(0.036)\end{array}$ \\
\hline$P$ & & & & $\begin{array}{c}1.316 \\
(0.040)\end{array}$ & & \\
\hline$\gamma$ & & & & & $\begin{array}{l}0.783 \\
(0.02)\end{array}$ & \\
\hline$\theta$ & & & & $\begin{array}{c}1.589 \\
(0.165)\end{array}$ & $\begin{array}{c}0.281 \\
(0.079)\end{array}$ & \\
\hline Industry fixed effects & Yes & Yes & Yes & Yes & Yes & Yes \\
\hline Cohort fixed effects & Yes & Yes & Yes & Yes & Yes & Yes \\
\hline Observations & 201877 & 200139 & 185671 & 201877 & 201877 & 201877 \\
\hline
\end{tabular}

Notes: All estimates restricted to firms employing at least six workers at the time of entry. Start-up size defined as the log of employment at the time of entry. Start-up wage defined as the log of firm average wage measured at the time of entry. In Column (2) WMFs in which the average value of the employee-to-member ratio during their spells is greater than $20 \%$ are excluded. In Column (3), the tax burden variable is lagged three months. All estimates include 4 industry dummies (distinguishing Manufacturing, Transport, Services and Other Sectors) and 13 cohort dummies. The hazard ratio is obtained computing $\exp \left(\beta^{\text {coop }}\right)$. Columns (1)(3) report Cox model estimates. Columns (4)-(5) report estimates of parametric frailty models that control for unobserved observation-specific effects and assume a Weibull and Log-logistic distribution of the baseline hazard respectively. The frailty term is assumed to follow a gamma distribution with mean 1 and variance $\theta$. Column (6) reports the estimate of a Generalized Gamma model. In Column(5)-(6), the effect of the covariates must be interpreted in terms of survival time (Accelerated Failure Time metric) and not in terms of the hazard. Robust standard errors in parentheses. Standard errors are clustered at the firm level. * Statistically significant at .10 level; $* *$ at the .05 level; $* * *$ at the .01 level 
Table A4. Employer payroll tax rate by sector

\begin{tabular}{|c|c|c|}
\hline Period & General tax rate & Total and partial tax exemptions \\
\hline 1997 & $12.5 \%$ & $\begin{array}{c}0 \% \text { - Education } \\
6.25 \% \text { - Manufacturing }\end{array}$ \\
\hline 1998 & $12.5 \%$ & $\begin{array}{l}0 \% \text { - Education } \\
6.25 \% \text { - Manufacturing }\end{array}$ \\
\hline 1999 & $12.5 \%$ & $\begin{array}{c}0 \% \text { - Education } \\
6.25 \% \text { - Manufacturing }\end{array}$ \\
\hline 2000 & $12.5 \%$ & $\begin{array}{l}0 \% \text { - Education } \\
6.25 \% \text { - Manufacturing, Freight transport by road (from October 2000) }\end{array}$ \\
\hline 2001 & $12.5 \%$ & $\begin{array}{l}\text { 0\%- Education } \\
\text { 6.25\%- Manufacturing, Freight transport by road (until May 2001) } \\
\text { 0\%- Urban and suburban passenger land transport, Manufacturing, Freight } \\
\text { transport by road (from June 2001) }\end{array}$ \\
\hline 2002 & $12.5 \%$ & $\begin{array}{l}\text { 0\%- Education, Taxicabs (from May 2002), Urban and suburban passenger } \\
\text { land transport, Manufacturing, Freight transport by road }\end{array}$ \\
\hline 2003 & $12.5 \%$ & $\begin{array}{l}\text { 0\%- Education, Taxicabs, Urban and suburban passenger land transport, } \\
\text { Manufacturing, Freight transport by road }\end{array}$ \\
\hline 2004 & $12.5 \%$ & $\begin{array}{c}\text { 0\%- Education, Taxicabs, Urban and suburban passenger land transport, } \\
\text { Manufacturing, Freight transport by road }\end{array}$ \\
\hline 2005 & $12.5 \%$ & $\begin{array}{c}\text { 0\%- Education, Taxicabs, Urban and suburban passenger land transport } \\
\text { Manufacturing, Freight transport by road }\end{array}$ \\
\hline 2006 & $12.5 \%$ & $\begin{array}{c}\text { 0\%-Education, Taxicabs, Urban and suburban passenger land transport, } \\
\text { Manufacturing, Freight transport by road }\end{array}$ \\
\hline 2007 & $\begin{array}{l}7.5 \% \\
\text { (from July 2007) }\end{array}$ & $\begin{array}{l}\text { 0\%- Education, Taxicabs, Manufacturing, Freight transport by road (until } \\
\text { June 2007), Urban and suburban passenger land transport }\end{array}$ \\
\hline 2008 & $7.5 \%$ & $0 \%$ - Education, Taxicabs, Urban and suburban passenger land transport \\
\hline 2009 & $7.5 \%$ & $0 \%$ - Education, Taxicabs, Urban and suburban passenger land transport \\
\hline
\end{tabular}


Table A5. Comparison of AIC values for several parametric models

\begin{tabular}{lcccc}
\hline \hline & Log Likelihood & K & C & AIC \\
\hline \hline Exponential & -5427.0172 & 20 & 1 & 10896.0344 \\
Weibull & -5418.7098 & 20 & 2 & 10881.4196 \\
Gompertz & -5378.1049 & 20 & 2 & 10800.2098 \\
Log-normal & -5335.0687 & 20 & 2 & 10714.1374 \\
Log-logistic & -5349.2146 & 20 & 2 & 10742.4292 \\
Generalized Gamma & -5334.9943 & 20 & 3 & 10715.9886 \\
\hline \hline
\end{tabular}

Notes: $\mathrm{k}$ is the number of model covariates and $\mathrm{c}$ the number of model-specific distributional parameters. $A I C=-2 \ln L+2(k+c)$. All estimates restricted to firms employing at least six workers at the time of entry.

Table A6. Macroeconomic performance of the Uruguayan economy. Period 1999-2007

\begin{tabular}{lccccccccc}
\hline \hline & 1999 & 2000 & 2001 & 2002 & 2003 & 2004 & 2005 & 2006 & 2007 \\
\hline GDP growth rate & $-1.94 \%$ & $-1.93 \%$ & $-3.84 \%$ & $-7.73 \%$ & $0.81 \%$ & $5.00 \%$ & $7.46 \%$ & $4.10 \%$ & $6.54 \%$ \\
Inflation & $4.17 \%$ & $5.05 \%$ & $3.59 \%$ & $25.94 \%$ & $10.19 \%$ & $7.59 \%$ & $4.9 \%$ & $6.38 \%$ & $8.5 \%$ \\
Unemployment rate & $11.3 \%$ & $13.6 \%$ & $15.3 \%$ & $17 \%$ & $16.9 \%$ & $13.1 \%$ & $12.2 \%$ & $11.4 \%$ & $9.6 \%$ \\
Real wage growth rate & $0.90 \%$ & $-1.19 \%$ & $-0.85 \%$ & $-10.89 \%$ & $-12.79 \%$ & $-1.45 \%$ & $4.02 \%$ & $4.99 \%$ & $4.55 \%$ \\
\hline \hline
\end{tabular}

Notes: Real wage growth rate only computed for workers employed in the private sector. The unemployment rate is the urban unemployment rate. Source: INE, BCU.

Table 5. Survival estimates under different macroeconomic conditions

\begin{tabular}{lcccc}
\hline \hline & \multicolumn{2}{c}{ Cox model } & \multicolumn{2}{c}{ Exponential model } \\
\hline \hline & Period & Period & Period & Period \\
& $1999-2002$ & $2004-2007$ & $1999-2002$ & $2004-2007$ \\
\hline \hline & & & & \\
Coop & -0.435 & $-0.518^{* * *}$ & $-0.437^{*}$ & $-0.523^{* * *}$ \\
& $(0.265)$ & $(0.195)$ & $(0.265)$ & $(0.197)$ \\
Firm start-up size & $-0.102^{*}$ & 0.064 & -0.100 & 0.065 \\
& $(0.062)$ & $(0.050)$ & $(0.062)$ & $(0.051)$ \\
Firm start-up wage & $-0.183^{* * *}$ & $-0.285^{* * *}$ & $-0.183^{* * *}$ & $-0.288^{* * *}$ \\
& $(0.041)$ & $(0.036)$ & $(0.041)$ & $(0.036)$ \\
Hazard ratio & $\mathbf{0 . 6 4 7}$ & $\mathbf{0 . 5 9 6}$ & $\mathbf{0 . 6 4 6}$ & $\mathbf{0 . 5 9 3}$ \\
Industry fixed effects & Yes & Yes & Yes & Yes \\
Cohort fixed effects & Yes & Yes & Yes & Yes \\
Observations & 49762 & 86301 & 49762 & 86301 \\
\hline \hline
\end{tabular}

Notes: All estimates restricted to firms employing at least six workers at the time of entry. Start-up size defined as the $\log$ of employment at the time of entry. Start-up wage defined as the log of firm average wage measured at the time of entry. All estimates include 4 industry dummies (distinguishing Manufacturing, Transport, Services and Other Sectors) and 13 cohort dummies. The hazard ratio is obtained computing $\exp \left(\beta^{\text {coop }}\right)$. Robust standard errors in parentheses. Standard errors are clustered at the firm level.* Statistically significant at .10 level; ** at the .05 level; *** at the .01 level 
Table 6. Employment stability, wage flexibility, wage growth and firm survival. Cox model estimates

\begin{tabular}{lcccc}
\hline \hline & $(1)$ & $(2)$ & $(3)$ & $(4)$ \\
\hline \hline & & & & \\
Coop & $-0.511^{* * *}$ & $-0.518^{* * *}$ & $-0.309^{*}$ & $-0.369^{* *}$ \\
& $(0.166)$ & $(0.164)$ & $(0.161)$ & $(0.161)$ \\
Firm start-up size & 0.046 & -0.023 & -0.035 & -0.065 \\
& $(0.04)$ & $(0.042)$ & $(0.041)$ & $(0.041)$ \\
Firm start-up wage & $-0.200^{* * *}$ & $-0.137^{* * *}$ & $-0.147^{* * *}$ & $-0.115^{* * *}$ \\
& $(0.028)$ & $(0.030)$ & $(0.028)$ & $(0.028)$ \\
Wage variability & & $0.781^{* * *}$ & & $0.628^{* * *}$ \\
& & $(0.103)$ & & $(0.099)$ \\
Employment variability & & & $0.817^{* * * *}$ & $0.628^{* * *}$ \\
& & & $(0.072)$ & $(0.074)$ \\
Hazard ratio & $\mathbf{0 . 6 0 0}$ & $\mathbf{0 . 5 9 6}$ & $\mathbf{0 . 7 3 4}$ & $\mathbf{0 . 6 9 1}$ \\
Industry fixed effects & Yes & Yes & Yes & Yes \\
Cohort fixed effects & Yes & Yes & Yes & Yes \\
Observations & 194894 & 194894 & 194894 & 194894 \\
\hline \hline
\end{tabular}

Notes: All estimates restricted to firms having at least 12 monthly records and employing at least six workers at the time of entry. Start-up size defined as the log of employment at the time of entry. Start-up wage defined as the log of firm average wage measured at the time of entry. Wage growth defined as the annual change in the log of firm-average wage. Employment and wage variability measured as the standard deviation of annual changes in the $\log$ of employment and wages respectively. All estimates include 4 industry dummies (distinguishing Manufacturing, Transport, Services and Other Sectors) and 13 cohort dummies. The hazard ratio is obtained computing $\exp \left(\beta^{\text {coop }}\right)$. Robust standard errors in parentheses. Standard errors are clustered at the firm level. *Statistically significant at .10 level; ** at the .05 level; *** at the .01 level. 
Table A7. Employment stability, wage flexibility, wage growth and post-2003 firm survival.

\begin{tabular}{|c|c|c|c|c|c|c|c|c|}
\hline & \multicolumn{4}{|c|}{ Cox model } & \multicolumn{4}{|c|}{ Exponential model } \\
\hline & $(1)$ & $(2)$ & (3) & $(4)$ & $(5)$ & $(6)$ & $(7)$ & $(8)$ \\
\hline Coop & $\begin{array}{c}-0.643 * * \\
(0.327)\end{array}$ & $\begin{array}{c}-0.594 * \\
(0.326)\end{array}$ & $\begin{array}{l}-0.473 \\
(0.326)\end{array}$ & $\begin{array}{l}-0.476 \\
(0.326)\end{array}$ & $\begin{array}{l}-0.652 * \\
(0.335)\end{array}$ & $\begin{array}{l}-0.602 * \\
(0.334)\end{array}$ & $\begin{array}{l}-0.476 \\
(0.334)\end{array}$ & $\begin{array}{l}-0.479 \\
(0.335)\end{array}$ \\
\hline Firm start-up size & $\begin{array}{l}0.0053 \\
(0.078)\end{array}$ & $\begin{array}{l}-0.008 \\
(0.075)\end{array}$ & $\begin{array}{l}-0.035 \\
(0.077)\end{array}$ & $\begin{array}{l}-0.033 \\
(0.076)\end{array}$ & $\begin{array}{c}0.011 \\
(0.081)\end{array}$ & $\begin{array}{l}-0.002 \\
(0.078)\end{array}$ & $\begin{array}{l}-0.026 \\
(0.079)\end{array}$ & $\begin{array}{l}-0.025 \\
(0.078)\end{array}$ \\
\hline Firm start-up wage & $\begin{array}{c}-0.228 * * * \\
(0.052)\end{array}$ & $\begin{array}{c}-0.177 * * * \\
(0.052)\end{array}$ & $\begin{array}{c}-0.203 * * * \\
(0.052)\end{array}$ & $\begin{array}{c}-0.193 * * * \\
(0.053)\end{array}$ & $\begin{array}{c}-0.236^{* * * *} \\
(0.054)\end{array}$ & $\begin{array}{c}-0.184 * * * \\
(0.054)\end{array}$ & $\begin{array}{c}-0.212 * * * \\
(0.053)\end{array}$ & $\begin{array}{c}-0.203 * * * \\
(0.054)\end{array}$ \\
\hline Wage variability & & $\begin{array}{c}0.512 * * * \\
(0.145)\end{array}$ & & $\begin{array}{c}0.144 \\
(0.163)\end{array}$ & & $\begin{array}{c}0.515^{* * *} * \\
(0.148)\end{array}$ & & $\begin{array}{c}0.129 \\
(0.167)\end{array}$ \\
\hline Employment variability & & & $\begin{array}{c}0.949 * * * \\
(0.128)\end{array}$ & $\begin{array}{c}0.882 * * * \\
(0.146)\end{array}$ & & & $\begin{array}{c}0.986^{* * * *} \\
(0.133)\end{array}$ & $\begin{array}{c}0.924 * * * \\
(0.154)\end{array}$ \\
\hline Hazard ratio & 0.526 & 0.552 & 0.623 & 0.621 & 0.521 & 0.548 & 0.621 & 0.619 \\
\hline Industry fixed effects & Yes & Yes & Yes & Yes & Yes & Yes & Yes & Yes \\
\hline Cohort fixed effects & Yes & Yes & Yes & Yes & Yes & Yes & Yes & Yes \\
\hline Observations & 55601 & 55601 & 55601 & 55601 & 55601 & 55601 & 55601 & 55601 \\
\hline
\end{tabular}

Notes: The analysis is restricted to the post-2003 firm survival. All estimates restricted to firms having at least 12 monthly records in the pre-2004 period and employing at least six workers at the time of entry. Start-up size defined as the log of employment at the time of entry. Start-up wage defined as the log of firm average wage measured at the time of entry. Wage growth rates defined as the annual change in the log of firm-average wage (measured in the pre-2004 period). Employment and wage variability measured as the standard deviation of annual changes in the log of employment and wages respectively (measured in the pre2004 period). All estimates include 4 industry dummies (distinguishing Manufacturing Transport Services and Other Sectors) and 13 cohort dummies. The hazard ratio is obtained computing $\exp \left(\beta^{\text {coop }}\right)$. Robust standard errors in parentheses. Standard errors are clustered at the firm level. * Statistically significant at .10 level; ** at the .05 level; *** at the .01 level. 